\title{
Effects of biochar on soil available inorganic nitrogen: A review and meta-analysis
}

Thi Thu Nhan Nguyen, ${ }^{\mathrm{a}, \mathrm{b}}$, Cheng-Yuan Xu ${ }^{\mathrm{a}, \mathrm{b}, \mathrm{c}}$, Iman Tahmasbian ${ }^{\mathrm{b}}$, Rongxiao Che,e,f, Zhihong Xü, Xuhui Zhou ${ }^{\mathrm{d}}$, Helen M. Wallace ${ }^{\mathrm{a}}$, Shahla Hosseini Bai ${ }^{\mathrm{a}, \mathrm{b}}$

${ }^{\mathrm{a}}$ Faculty of Science, Health, Education and Engineering, University of the Sunshine Coast, Maroochydore DC, QLD 4558, Australia

${ }^{\mathrm{b}}$ Environmental Futures Research Institute, School of Natural Sciences, Griffith University, Nathan, Brisbane, Queensland 4111, Australia

${ }^{\mathrm{c}}$ School of Medical and Applied Sciences, Central Queensland University, Bundaberg, Queensland 4670, Australia

${ }^{\mathrm{d}}$ School of Ecological and Environmental Sciences, East China Normal University, Shanghai 200241, China

${ }^{\mathrm{e}}$ College of Life Sciences, University of Chinese Academy of Sciences, Beijing 100049, China

${ }^{\mathrm{f}}$ Sino-Danish Center for Education and Research / Sino-Danish College, University of Chinese Academy of Sciences, Beijing 100049, China

Corresponding author: thu.nhan@research.usc.edu.au / nhan.nguyen@griffith.edu.au

\section{ABSTRACT}

The interaction between biochar and soil changes nitrogen $(\mathrm{N})$ dynamics in different ecosystems. Although multiple studies have reported influences of biochar on soil inorganic N (SIN) including ammonium $\left(\mathrm{NH}_{4}{ }^{+}-\mathrm{N}\right)$ and nitrate $\left(\mathrm{NO}_{3}{ }^{-} \mathrm{N}\right)$, the influences reported are contradictory. We undertook a meta-analysis to investigate how biochar properties and the interaction among biochar, soil and fertilisation affect SIN. This quantitative analysis used 56 studies with 1080 experimental cases from manuscripts published between 2010 and 2015. Overall, we found that biochar reduced SIN regardless of experimental conditions (approximately $-11 \pm 2 \%$ of $\mathrm{NH}_{4}{ }^{+}-\mathrm{N}$ and $-10 \pm 1.6 \%$ of $\mathrm{NO}_{3}{ }^{-}-\mathrm{N}$ ); however, $95 \%$ of cases were observed within one year after biochar application. SIN was best explained by residence time of biochar in soil, pyrolysis temperature, application rate, fertiliser type, and soil $\mathrm{pH}$. The effects of biochar were complex due to the interaction of biochar with environmental factors. Most biochar trials used wood as a feedstock, but woody biochar did not 
decrease SIN as much as other plant-derived biochars. When biochar was used with $\mathrm{NH}_{4}$-based fertilisers, SIN decreased compared to biochar with no fertiliser. In contrast, adding organic fertiliser with biochar increased SIN compared to biochar alone. SIN was clearly reduced after one month of biochar application, suggesting that biochar should be applied at least one month prior to planting so plants are not affected by decreased N. Our results revealed that the interactions between biochar and environmental factors, pyrolysis temperature of biochar and biochar surface properties are the main driving factors affecting SIN. There were limited long term studies of greater than 1 year, thus the long term effects of biochar on SIN still remain unclear.

\section{Keywords}

Biochar, charcoal, systematic review, boosted regression tree, nitrogen, fertiliser

\section{Introduction}

Nitrogen $(\mathrm{N})$ is one of the most critical elements for plant growth and productivity (Atkinson et al., 2010; Bai et al., 2012; Reverchon et al., 2014; Bai et al., 2016). In particular, soil inorganic nitrogen (SIN) is an important $\mathrm{N}$ source for plants because plants uptake inorganic $\mathrm{N}$ directly through the rooting system (Lynch, 1995). However, N loss via leaching and volatilisation leads to reduced crop productivity, eutrophication, excess nitrate in groundwater, and increased nitrous oxide $\left(\mathrm{N}_{2} \mathrm{O}\right)$ emissions (Overrein, 1969; Bradbury et al., 1993; Xing \& Zhu, 2000; Mikkelsen \& Hartz, 2008).

Biochar is a promising soil additive to reduce $\mathrm{N}$ loss and improve soil fertility (Lal, 2009; Joseph et al., 2013). Biochar is a carbon (C) rich material produced by pyrolysis of biomass at relatively low temperatures $\left(<700^{\circ} \mathrm{C}\right)$ without oxygen $\left(\mathrm{O}_{2}\right)$ (Lehmann \& Joseph, 2009). There are contradictory reports regarding $\mathrm{N}$ availability when biochar is applied including decrease, increase and no effect (Blackwell et al., 2009; Clough et al., 2013; Bai et al., 2015b; Xu et al., 2015). However, these studies have not yet been synthesised; therefore, a systematic analysis of the relationship between biochar and SIN is necessary. This study aimed to (a) investigate possible mechanisms influencing 
SIN when biochar is applied through a short review of available published studies and (b) use a metaanalysis to explore the general trends in $\mathrm{NH}_{4}{ }^{+}-\mathrm{N}$ and $\mathrm{NO}_{3}{ }^{-}-\mathrm{N}$ across multiple studies in the presence of biochar.

\section{Overview of the mechanisms affecting soil inorganic $\mathbf{N}$ after biochar application}

2.1. Abiotic mechanisms - adsorption/desorption

Chemisorption of SIN by biochar is based on functional groups (Lehmann \& Joseph, 2009). Acid functional groups include carboxylic, hydroxyl, lactone and lactol groups on the surface of biochar (Brennan et al., 2001; Amonette \& Joseph, 2009). Carboxylic groups are strong Bronsted acids; less acidic groups include phenols and carbonyls. They have a negative charge and adsorb $\mathrm{NH}_{4}{ }^{+}-\mathrm{N}$ by electrostatic attraction (Montes-Morán et al., 2004; Zheng et al., 2010). In general, $\mathrm{NO}_{3}{ }^{-} \mathrm{N}$ adsorption by biochar is weak because biochar carries greater negative surface charges than positive surface charges (Kameyama et al., 2012). However, the existence of base functional groups including chromenes, ketones and pyrones on biochar can facilitate $\mathrm{NO}_{3}{ }^{-}-\mathrm{N}$ adsorption to biochar (MontesMorán et al., 2004; Amonette \& Joseph, 2009). $\mathrm{NO}_{3}{ }^{-} \mathrm{N}$ adsorption is also possible via unconventional H-bonding between $\mathrm{NO}_{3}{ }^{-} \mathrm{N}$ ions and the biochar surface (Mukherjee et al., 2011; Lawrinenko, 2014; Kammann et al., 2015).

SIN adsorption by biochar is also time dependent and varies with the temperature and feedstock used to produce biochar. Over time, oxygen-containing acid functional groups (e.g. carboxyl and hydroxyl) are formed on the biochar surface leading to increased biochar CEC and the potential to adsorb more $\mathrm{NH}_{4}{ }^{+} \mathrm{N}$ than fresh biochar. During the ageing of biochar in the soil, $\mathrm{NO}_{3}{ }^{-} \mathrm{N}$ chemisorption through H-bonding may be enhanced because biochar becomes more hydrophilic (Hammes \& Schmidt, 2009). The effect of feedstock on $\mathrm{NO}_{3}{ }^{-} \mathrm{N}$ adsorption and the mechanisms of $\mathrm{NO}_{3}{ }^{-}-\mathrm{N}$ adsorption by aged biochar through $\mathrm{H}$-bonding remain unclear and need further research (Clough et al., 2013; Kammann et al., 2015). 
Sorption capacity of biochar decreases with increased pyrolysis temperature (Mukherjee et al., 2011; Gai et al., 2014). At high temperatures $\left(>600^{\circ} \mathrm{C}\right)$, acidic functional groups (mainly carboxyl) are converted to neutral or basic fused aromatic groups due to the loss of oxygen-containing functional groups, leading to decreased CEC (Cheng et al., 2008; Gaskin et al., 2008; Kookana et al., 2011; Gai et al., 2014). Therefore, aged biochar produced at lower temperatures are expected to adsorb more $\mathrm{NH}_{4}{ }^{+}-\mathrm{N}$ compared to the fresh and high temperature biochar.

The feedstock used to produce biochar influences acid (carboxylic) functional groups in biochar to adsorb $\mathrm{NH}_{4}{ }^{+}-\mathrm{N}$ (Kookana et al., 2011). For example, grassy biochars (produced from cordgrass) have a higher concentration of carboxylic groups than woody biochars (produced from honey mesquite and loblolly pine), and thus the sorption capacity of the grassy biochars is higher than the woody biochar (Harvey et al., 2012). The higher concentration of carboxylic functional groups is probably because of a high concentration of cellulose, alkali salts and alkali metal oxides in their feedstock (Harvey et al., 2012). Lignocellulose fragments in grassy feedstocks are oxidised more efficiently during pyrolysis and cycloreversion oxidation occurs more rapidly to carboxylic acids. These processes are less efficient in woody feedstocks, owing to a reduced surface charge at any pyrolysis temperature compared with grassy feedstocks (Harvey et al., 2012).

Additionally, physisorption happens inside the pores and on the inner surface of biochar (Lehmann \& Joseph, 2009; Saleh et al., 2012; Clough et al., 2013). The inner-surface area of biochar has a positive correlation with the adsorption capability of biochar (Zhang et al., 2012). A commonly used surface area measurement is BET surface area, calculated by determining the adsorption of gases in multimolecular layers (Brunauer et al., 1938). For example, the BET surface area of biochar from beetroot chips and spent brewer's grains is 10 times higher than BET of hydrochar from the same feedstocks, leading to increased $\mathrm{NH}_{4}{ }^{+}-\mathrm{N}$ adsorption due to increased physisorption (Bargmann et al., 2014). Generally, biochars produced from high temperatures and slow pyrolysis possess higher BET and pore volume, and have a higher physisorption capacity (Lua et al., 2004; Downie et al., 2009; 
Kookana et al., 2011; Bruun et al., 2012). At high temperature $\left(>600^{\circ} \mathrm{C}\right)$, biochar surface area and pores are enhanced due to the enhancement of crystallites and their ordered structure (Downie et al., 2009). However, when the temperature reaches a threshold (e.g. pine biochar at $750^{\circ} \mathrm{C}$, wheat residue biochar at $700^{\circ} \mathrm{C}$ ), deformation occurs, micropore structure is destroyed and surface area decreases (Chun et al., 2004; Brown et al., 2006; Downie et al., 2009). Slow pyrolysis conditions also enhance BET, for example BET of wheat straw biochars are 0.6 and $1.6 \mathrm{~m}^{2} \mathrm{~g}^{-1}$ for fast and slow pyrolysis, respectively (Bruun et al., 2012). The longer retention times of slow pyrolysis enables micropores to form (Downie et al., 2009).

Some studies report that some of the adsorbed $\mathrm{N}$ compounds could be desorbed over time and become available (Rosa \& Knicker, 2011; Kameyama et al., 2012; Taghizadeh-Toosi et al., 2012a). Desorption of SIN probably depends on SIN adsorption capacity of biochar which is related to biochar properties, biochar application rate, evolution of soil anion and cation exchange capacity, $\mathrm{N}$ loading capacity of ecosystems, soil hydraulic characteristics, climate conditions, soil type, and $\mathrm{N}$ demands of plants and microorganisms (Clough et al., 2013).

\subsection{Biotic mechanisms}

\subsubsection{Mineralisation}

Biochar can increase, decrease or have no effect on the conversion of organic $\mathrm{N}$ to inorganic $\mathrm{N}$ (soil $\mathrm{N}$ mineralisation) (Hart et al., 1994; Kuzyakov et al., 2009; Spokas et al., 2010; Zimmerman et al., 2011; Singh \& Cowie, 2014). Biochar effects on N mineralisation depend on feedstock, pyrolysis temperature, time after application, and biochar C:N ratio (Chan \& Xu, 2009; Zavalloni et al., 2011; Zimmerman et al., 2011; Clough et al., 2013).

Priming effect, the change in the mineralization of native soil organic matters (SOM) due to the addition of new substrates, could be affected by biochar amendment (Zimmerman et al., 2011). Different pyrolysis temperatures and feedstock can modify the priming effect of biochar because 
temperature and feedstock influence the content of biochar labile organic compounds, which determine the rate of the priming effect (Luo et al., 2011; Zimmerman et al., 2011; Singh et al., 2012). For example, biochars produced at low temperatures $\left(<400^{\circ} \mathrm{C}\right)$ lead to a higher mineralisation rate than those from high temperature $\left(>525^{\circ} \mathrm{C}\right)$ due to higher readily decomposable organic $\mathrm{C}$ content (Luo et al., 2011; Zimmerman et al., 2011; Singh et al., 2012). Manure biochar is likely to stimulate $\mathrm{N}$ mineralisation more than plant-based biochars owing to the lower $\mathrm{C}: \mathrm{N}$ ratio (Singh et al., 2012). Generally, a high $\mathrm{N}$ feedstock stimulates $\mathrm{N}$ mineralisation (Thies et al., 2015).

Mineralisation is a time-dependent process (Zimmerman et al., 2011). The priming effect caused by biochar is observed immediately after application (Luo et al., 2011), or shortly after application (90 days) (Zimmerman et al., 2011). The priming effect on $\mathrm{N}$ mineralisation is generally a short-term event (Zimmerman et al., 2011; Naisse et al., 2015). The positive priming effect happens initially because biochar as a new $\mathrm{C}$ source stimulates soil microbes to mineralise biochar-labile organic compounds; consequently, the remineralisation and co-metabolisation of SOM occur (Kuzyakov et al., 2000; Kuzyakov et al., 2009; Singh \& Cowie, 2014). However, in the long term (e.g. 250-500 days in Zimmerman et al., 2011), N mineralisation decreases because organic matters are adsorbed on biochar surfaces, or in soil pores to make them less accessible for microorganisms. As a result, they become unavailable to soil microorganisms as a nutrient source and the mineralisation rate decreases.

Briefly, $\mathrm{N}$ mineralisation is a short term process; therefore potential increases of SIN due to the biochar priming effect may not be detected if soil is not examined soon after biochar application. It is also unclear to what extent different biochars can increase $\mathrm{N}$ mineralisation when they interact with soils and fertilisers. Further long term studies of biochar and native SOM are necessary to understand the effects of biochar on $\mathrm{N}$ mineralisation.

2.2.2. Immobilisation 
Both $\mathrm{NH}_{4}^{+}-\mathrm{N}$ and $\mathrm{NO}_{3}{ }^{-}-\mathrm{N}$ can be assimilated by microbes and be unavailable for plant uptake through microbial immobilisation, the uptake of inorganic $\mathrm{N}$ by microorganisms (Hart et al., 1994). Soil microorganisms use labile organic compounds in fresh low-temperature biochar as a nutrient source for immobilisation (Smith et al., 2010; Bruun et al., 2011; Clough et al., 2013). Compounds containing acid-hydrolysable N (e.g. amino sugars, amino acids) in biochars are used readily by soil microorganisms (Rosa \& Knicker, 2011; Wang et al., 2012). Such immobilisation can occur in as little as 10 days after biochar application (Bruun et al., 2011; Zhang et al., 2012). The evidence of enhanced $\mathrm{N}$ immobilisation is the combination of SIN decline and the increase in microbial abundances associated with $\mathrm{N}$ cycling and $\mathrm{CO}_{2}$ emissions due to microbial respiration (Deenik et al., 2010; Lentz \& Ippolito, 2011; Zhang et al., 2012; Ducey et al., 2013). There are several factors affecting $\mathrm{N}$ immobilisation including feedstock, $\mathrm{C}: \mathrm{N}$ ratio of biochar, $\mathrm{C}: \mathrm{N}$ ratio of co-amended organic substrate (see section 2.2.1 of this article), and the abundance of substrates that can be used by soil microorganisms (Zavalloni et al., 2011). Woody biochar is assumed to stimulate $\mathrm{N}$ immobilisation but the extent of stimulation remains uncertain because woody biochar is more recalcitrant than other biochars (Lehmann et al., 2006; DeLuca et al., 2015).

The $\mathrm{C}: \mathrm{N}$ ratio of biochar determines whether biochar will trigger $\mathrm{N}$ immobilisation or mineralisation (Chan \& Xu, 2009). The $\mathrm{C}: \mathrm{N}$ of 20 is the threshold; if the ratio is above $20, \mathrm{~N}$ immobilisation occurs; when the ratio is lower than $20, \mathrm{~N}$ mineralisation happens (Chan \& $\mathrm{Xu}, 2009$ ). In reality, this threshold ranges between 20 and 32 (Kuzyakov et al., 2000; Sullivan \& Miller, 2001). The C:N ratio of the soil also can be used to explain the priming effect; soil C:N over 32 stimulates $\mathrm{N}$ immobilization (Novak et al., 2010; Zavalloni et al., 2011; Bruun et al., 2012; Xu et al., 2015).

\subsubsection{Nitrification}

The addition of biochar into the soil may moderate soil temperature, enhance soil moisture and aeration, and thus stimulate nitrifier activities (Mukherjee \& Lal, 2013; Zhang et al., 2013; Ulyett et al., 2014). Biochar reduces diurnal and seasonal temperature variations due to the combined 
modification of soil thermal conductivity and reflectance (Zhang et al., 2013). Biochar retains water in its pores, reduces soil bulk density and increases soil porosity, adsorbs nitrifier inhibitors from soil (e.g. phenolics), and thus stimulates nitrification (Berglund et al., 2004; Gundale \& DeLuca, 2006; Joseph et al., 2009; Mukherjee \& Lal, 2013). In general, biochar application may activate nitrifiers including ammonia oxidising archaea (AOA) and ammonia oxidising bacteria in aerobic conditions (Thies et al., 2015). However, in water saturated conditions, there is no correlation between AOA, AOB and biochar application (Harter et al., 2014; Thies et al., 2015). In aerobic field soil, gene copy numbers of AOA increased by 1.5 times and $\mathrm{AOB}$ increased by 1.7 times when amended with biochar and NPK fertiliser, corresponding with the increased net nitrification rate in amended soil (Prommer et al., 2014; Bai et al., 2015a). However, it may take over one year for biochar to provide habitat for nitrifiers to colonise (Prommer et al., 2014; Bai et al., 2015a). Similar results have been obtained in aerobic laboratory experiments (Song et al., 2014). Redox reactions in soil are enhanced through the interactions with biochar surfaces and within pores, resulting in boosted $\mathrm{NH}_{4}{ }^{+}-\mathrm{N}$ oxidation efficiency and increased AOA and AOB copy numbers (Joseph et al., 2010; Thies et al., 2015).

Nitrifiers are very sensitive to soil pH (De Boer \& Kowalchuk, 2001; Sahrawat, 2008). Nitrification halts when $\mathrm{pH}$ is lower than 5.0, and occurs rapidly when $\mathrm{pH}$ is over 6.0 (Sahrawat, 2008). Most biochars are alkaline and have a liming effect on acidic soils (Brandstaka et al., 2010; Cayuela et al., 2013b). The main forms of alkalinity in biochars include oxygen-containing organic functional groups on their surfaces, mineral deposits such as $\mathrm{CaCO}_{3}$, and soluble base cations that are formed during pyrolysis or inherited from feedstocks (Singh et al., 2010; van Zwieten et al., 2010a; Yuan et al., 2011). Studies on acidic soils with alkaline biochar treatment demonstrated increased nitrification rates in soil (Clough et al., 2010; Ulyett et al., 2014; Zhao et al., 2014). However, the effects of biochar on nitrification in alkaline soils remain unanswered (Cayuela et al., 2013b). 
Substrate $\left(\mathrm{NH}_{4}{ }^{+}-\mathrm{N}\right)$ abundance and availability also affect nitrification; therefore inorganic $\mathrm{NH}_{4}{ }^{-}$ based or organic fertiliser combined with biochar creates favourable conditions for nitrifying activities (Sahrawat, 2008; Prommer et al., 2014). Adding inorganic fertiliser may stimulate nitrification due to increase substrate availability, and organic fertiliser can stimulate nitrification through increased organic matter (Song et al., 2014; Zhao et al., 2014).

Nitrification inhibitors in some biochars cause nitrification reduction (Clough et al., 2010). Biochar may contain bactericidal and fungicidal compounds such as acetaldehyde, aldehydes, $\alpha$ - and $\beta$ pinene, pinecarveol, and ethylene which limit microbial activities in general (Simpson \& McQuilkin, 1976; Painter, 1998; Kurose et al., 2007; Clough et al., 2010; Spokas et al., 2010). The content of volatile organic compounds (VOCs) in biochar determines the bactericidal ability of biochar and depends on pyrolysis temperature and feedstock type (Clough et al., 2010). For example $\alpha$-pinene, was still retained in biochar made from Pinus after thermal decomposition and it restricted nitrifiers i.e. Nitrosomonas (Ward et al., 1997). The extent in which biochar VOCs effects on nitrification and possible $\mathrm{NO}_{3}{ }^{-} \mathrm{N}$ availability remains unanswered in published studies. However, the effects of bactericidal compounds are likely to be transient and minimal since their lifetime in soil is short (Zackrisson et al., 1996; Jeffery et al., 2015).

\subsubsection{Denitrification}

Denitrification decreases $\mathrm{NO}_{3}^{-}-\mathrm{N}$ availability and is affected by biochar amendment. Biochar significantly decreases $\mathrm{N}_{2} \mathrm{O}$ by affecting denitrification processes (van Zwieten et al., 2009; Cayuela et al., 2013b; Clough et al., 2013; Thies et al., 2015). Generally, biochar can reduce $\mathrm{N}_{2} \mathrm{O}$ emissions by up to $50 \%$ through four possible mechanisms (Cayuela et al., 2013b).

(i) $\mathrm{N}_{2} \mathrm{O}$ can bind with functional groups on the biochar surface, particularly metal ions embedded in biochar (e.g. $\mathrm{Fe}$ or $\mathrm{Cu}$ ), and may be activated for $\mathrm{N}-\mathrm{N}$ or $\mathrm{N}-\mathrm{O}$ scission, leading to $\mathrm{N}_{2} \mathrm{O}$ emission reduction (Cayuela et al., 2013b). 
(ii) The substrate for microbes decreases through absorbing organic $\mathrm{C}$ or inorganic N. Biochar may limit the availability of $\mathrm{N}$ in soil, reducing substrates that produce $\mathrm{N}_{2} \mathrm{O}$ (Cayuela et al., 2013b). In some cases, biochar reduces denitrifiers because it adsorbs SOMs on its surface and incorporates them in organo-mineral fractions, thus reducing C sources for soil microbial activities (Joseph et al., 2010).

(iii) Microbial functional groups can change due to $\mathrm{pH}$ changes. The liming effect of biochar helps to mitigate $\mathrm{N}_{2} \mathrm{O}$ emission during denitrification because elevated $\mathrm{pH}$ reduces denitrification of $\mathrm{NO}_{2}{ }^{-}-\mathrm{N}$ from nitrification and synthesis/activity of the functional $\mathrm{N}_{2} \mathrm{O}$ reductase enzyme (Mørkved et al., 2007; Liu et al., 2010a; Bakken et al., 2012; Cayuela et al., 2013b).

(iv) Soil aeration is improved, thereby inhibiting denitrification (Heincke \& Kaupenjohann, 1999).

It has also been shown that under the effects of biochar, $\mathrm{N}_{2} \mathrm{O}$ emissions decreased whereas the abundance of nitrous oxide reductase (nosZ) gene increases (van Zwieten et al., 2010b; Harter et al., 2014; Bai et al., 2015a). Similarly, the abundance of nosZ, nirK and nirS (both nitrite reductase) genes increased with increased biochar application by up to 10\% (Ducey et al., 2013). Biochar favours the last step of denitrification (i.e. converting $\mathrm{N}_{2} \mathrm{O}$ to $\mathrm{N}_{2}$ ) in which nosZ mediates this process; the final result is $\mathrm{N}_{2} \mathrm{O}$ emission reduction (van Zwieten et al., 2010b; Cayuela et al., 2013a).

The crucial factors affecting $\mathrm{N}_{2} \mathrm{O}$ emission are biochar properties (feedstock, chemical properties), biochar application rate, and $\mathrm{N}$ fertiliser form (Cayuela et al., 2013b). Briefly, plant-derived feedstocks, fast pyrolysis, high $\mathrm{C}: \mathrm{N}$ ratio of biochar $(>30)$, high application rates $(>10 \%)$, and $\mathrm{NO}_{3^{-}}$ based fertiliser reduced $\mathrm{N}_{2} \mathrm{O}$ emissions the most (Cayuela et al., 2013b).

\subsubsection{Nitrogen fixation}

Biochar application impacts $\mathrm{N}_{2}$-fixing bacteria (diazotrophs) including both free-living and symbiotic soil bacteria; therefore biochar influences $\mathrm{N}$ fixation, the conversion of atmospheric $\mathrm{N}_{2}$ to ammonia $\left(\mathrm{NH}_{3}\right)$ (Giller, 2001; Thies et al., 2015). Free-living diazotrophs (e.g. Azotobacter sp. and 
Azospirillum) are stimulated in biochar treatments due to enlarged habitat with limited $\mathrm{O}_{2}$ inside biochar pores (Thies et al., 2015). Symbionts (e.g. rhizobia) in biochar treatments are also activated. In legumes, biochar enhances biological $\mathrm{N}$ fixation (nodulation and nitrogenase activity) leading to increased crop yield (Clough et al., 2013; Quilliam et al., 2013; Thies et al., 2015; Xu et al., 2015). Increased application rates of biochar increases nodulation of rhizobia due to increased availability of boron (B), molybdenum (Mo), K, P, and Ca (Rondon et al., 2007). Immobilisation and adsorption of biochar with soil $\mathrm{N}$ reduce available $\mathrm{N}$ for plant roots, thus stimulating $\mathrm{N}$ fixation and root nodulation (Rondon et al., 2007; Biederman \& Harpole, 2013; Thies et al., 2015). For example, biochar from soft wood chips reduced significantly soil $\mathrm{N}$ but significantly increased $\mathrm{N}$ fixation rate in alder (Robertson et al., 2012). In addition, biochar retains signalling molecules (e.g. nod factors) longer in soil by adsorption, and therefore increases the interaction between them and rhizobia bacteria, leading to enhanced nodulation (Thies et al., 2015). However, both short and long term studies of biochar effects on $\mathrm{N}$ fixation are still limited (Clough et al., 2013).

Briefly, the interaction between biochar and soil affects SIN via both abiotic and biotic pathways. However, which pathway is predominant remains unknown. For example, $\mathrm{N}$ immobilisation is expected to decrease $\mathrm{SIN}$ but if $\mathrm{N}$ mineralisation and nitrification are stronger, $\mathrm{SIN}$ is expected to increase in the soil. If SIN decreases, it means that $\mathrm{N}$ immobilisation and reduction processes are predominant and can be stimulated. The meta-analysis therefore may help to elucidate which pathway is stronger under certain conditions.

\subsection{Other factors affecting soil inorganic $\mathrm{N}$ after biochar application}

In the cropping system, the interaction between biochar and soil is not the only factor influencing SIN. There are other factors which may affect SIN, including the interactions between plant assimilation and fertilisation when biochar is applied.

\subsubsection{Plant assimilation}


Biochar alters soil $\mathrm{NO}_{3}{ }^{-}-\mathrm{N}$ and $\mathrm{NH}_{4}{ }^{+}-\mathrm{N}$ availability, affecting plant assimilation. Plants can assimilate various types of $\mathrm{N}$ including inorganic and organic N (Schimel \& Bennett, 2004; Boudsocq et al., 2012). The inorganic $\mathrm{N}$ preference is also different among different plant species; i.e. acid-soil plants prefer $\mathrm{NH}_{4}{ }^{+} \mathrm{N}$ while alkaline-soil plants prefer $\mathrm{NO}_{3}{ }^{-} \mathrm{N}$ (Rosnitschek-Schimmel, 1982; Hahne \& Schuch, 2004).

Biochar application improves plant uptake of SIN through different mechanisms (Chan et al., 2008) including (i) biochar improves soil moisture and $\mathrm{pH}$, so it stimulates $\mathrm{N}$ mineralisation and nitrification leading to improved plant uptake (Saarnio et al., 2013), (ii) the liming effect of biochar creates a more favourable root zone environment by reducing the impact of soil acidity and relatedtoxicity (e.g. aluminium in soil could inhibit root growth) (Delhaize \& Ryan, 1995; van Zwieten et al., 2010a), (iii) biochar increases $\mathrm{N}$ retention in soil by decreased leaching thus helping to increases inorganic $\mathrm{N}$ for plant assimilation (van Zwieten et al., 2010a). However, some studies did not observe any effect of biochar alone on $\mathrm{N}$ uptake, but observed a positive effect on $\mathrm{N}$ uptake when biochar was combined with $\mathrm{N}$ and $\mathrm{Mg}$ fertilisers (Dharmakeerthi et al., 2012). Currently we do not know how much plants affect SIN availability after biochar application.

Biochar also affects SIN indirectly through shifting root exudates, thereby influencing SOC turnover and biochar priming effects (Weng et al., 2015). Biochar also has potential to adsorb fresh root exudates (Joseph et al., 2010; Ameloot et al., 2013); additionally, microorganisms prefer the easily degradable root exudates than more recalcitrant SOC (Blagodatskaya et al., 2011). Biochar causes negative priming effects in the rhizosphere. When the ratio of root exudate $\mathrm{C}$ inputs to total soil $\mathrm{C}$ increases, rhizosphere priming effects are enhanced (Weng et al., 2015).

\subsubsection{Interaction with fertilisation}

$\mathrm{N}$ mineralisation could be stimulated when biochar is applied with organic fertiliser, glucose; cellulose and glucose; and ryegrass (Hamer et al., 2004; Nocentini et al., 2010; Luo et al., 2011; van 
Zwieten et al., 2013). This is due to the combined effects of available food sources for microorganisms and the habitat of the biochar surface (Chenu et al., 2001; Hamer et al., 2004). Bruun et al. (2011) observed $\mathrm{N}$ immobilisation in soil when applying biochar alone, but no $\mathrm{N}$ immobilisation was found when biochar was applied with slurry ( $\mathrm{C}: \mathrm{N}$ of 2.2$)$. When applying an inorganic substrate, the combination of inorganic fertiliser with biochar can offset the decrease of inorganic $\mathrm{N}$ due to $\mathrm{N}$ immobilisation, thus reducing $\mathrm{N}$ deficiency of plants (Prommer et al., 2014). However, to date it is unknown which fertiliser addition can be more beneficial to alleviate SIN reduction by biochar.

\section{Current knowledge: a quantitative analysis of the factors influencing the impact of biochar on soil inorganic $\mathbf{N}$}

There have been many studies which show the effects of biochar on soil $\mathrm{N}$ availability; however, results of these studies were contradictory. To the best knowledge of the authors, there is no metaanalysis to assess the effects of biochar on SIN to date. This meta-analysis aimed to answer the following questions (i) how biochar properties affect SIN and (ii) how the interactions between biochar properties and other factors (e.g. soil properties, fertiliser and crop type etc.) alter SIN. Based on the widely reported effects of biochar on SIN, we hypothesised that both biochar and soil properties would affect SIN due to changing soil biochemical properties after adding biochar to the soil.

\subsection{Methods}

3.1.1. Data sources and compilation

A literature search was undertaken of Google Scholar, USC Electronic Library, and Science Direct using keywords (biochar OR black carbon OR char OR hydrochar) AND (nitrogen OR N OR nitrate OR ammonium OR mineral N OR inorganic N) AND (soil) NOT (review) NOT (meta-analysis). Publications were included in the meta-analysis if they met the following criteria (1) at least 3 
replicates per treatment, (2) the original data on $\mathrm{NH}_{4}{ }^{+}-\mathrm{N}$ and $\mathrm{NO}_{3}{ }^{-}-\mathrm{N}$ content could be extracted from the manuscript (from tables and figures) including the mean and standard deviation (SD) or standard error (SE) of the mean; and (3) data collection was carried out based on paired observation between a control and a treatment with biochar. The control was subject to the same experimental conditions without a biochar treatment.

To minimise the effect of publication bias, some unpublished studies were included. We found 55 peer-reviewed manuscripts and 1 unpublished manuscript that met the criteria published between 01/2010 and 12/2015. The process was summarised in a PRISMA statement (Moher et al., 2009) (Fig. S1).

The data on biochar characteristics, soil properties, and experimental conditions were extracted from each study, including (1) biochar characteristics: feedstock, $\mathrm{pH}$, pyrolysis temperature, type of pyrolysis, C:N ratio, volatile organic matters (VOCs), $\% \mathrm{C}, \% \mathrm{~N}$, cation exchange capacity (CEC), BET surface area; (2) soil properties: soil texture, $\mathrm{pH}$, bulk density, $\% \mathrm{C}, \% \mathrm{~N}$; and (3) experimental conditions: pot-based or field-based experiment, crop types, biochar application rate, residence time of biochar in soil, $\mathrm{N}$ amendments (e.g. type of amendment, application rate, $\% \mathrm{C}, \% \mathrm{~N}$ ). The software Plot Digitizer 2.6.2 (Huwaldt, 2012) was used to extract data from figures. The data extracted was the mean of the control, the mean of the treatment, and standard deviation (SD) or standard error (SE). Where necessary, the corresponding authors were contacted to supply additional information.

The data were converted to the same units for comparison. Biochar application rate was converted from $\mathrm{t} \mathrm{ha}^{-1}$ to $\%$ by using bulk density (BD) of soil and soil depth to which biochar was applied. If BD was not reported, the Hydraulic Properties Calculator program was used to determine BD based on soil texture (Saxton \& Rawls, 2009). $\mathrm{pH}\left(\mathrm{CaCl}_{2}\right)$ and $\mathrm{pH}(\mathrm{KCl})$ were converted to $\mathrm{pH}\left(\mathrm{H}_{2} \mathrm{O}\right)$ by using the formulas:

$$
\mathrm{pH}\left(\mathrm{H}_{2} \mathrm{O}\right)=1.65+0.86 * \mathrm{pH}\left(\mathrm{CaCl}_{2}\right)\left(\mathrm{r}^{2}=0.70 ; \mathrm{P}<0.001\right) \text { (1) (Augusto et al., 2006) }
$$


$\mathrm{pH}\left(\mathrm{H}_{2} \mathrm{O}\right)=1.96+0.74 * \mathrm{pH}(\mathrm{KCl})\left(\mathrm{r}^{2}=0,57 ; \mathrm{P}<0,001\right)(2)$ (Augusto et al., 2006)

\subsubsection{Effect size}

The effect size was calculated by using the natural log-transformed response ratio (RR)

$\ln R R=\ln \left(\frac{X_{T}}{X_{C}}\right)(3)$

Where: $X_{T}$ is the mean of the biochar treatment and $X_{C}$ is the mean of the control group

All subsequent statistical analyses below used $\operatorname{lnRR}$ as the response variable.

\subsubsection{Mixed-effect model}

A random-effect model was selected for the meta-analysis except where the estimated pooled variance was $\leq 0$, in which a fixed effects model was used. The means and SD of the control and treatment of each study were recorded (as $\mathrm{NH}_{4}{ }^{+}-\mathrm{N}$ and $\mathrm{NO}_{3}{ }^{-}-\mathrm{N}$ content). The variance was calculated by using the SD or SE values.

The data of explanatory variables were then grouped in the following categories:

- Feedstock was grouped in five categories: (1) carbohydrates/non-lignocellulosic waste (fruit peels, beet-root chips, spent brewer's grains), (2) wood, (3) manure, (4) herbaceous waste (green waste, straws, and corn stover), and (5) lignocellulosic waste (walnut shells, peanut shells, maize cobs, furfural from corn cobs) (Rosillo-Calle et al., 2015).

- Pyrolysis temperature was grouped in four categories: (1) $\leq 400$, (2) 401-501, (3) 501-600, and (4) $>600$ (Cayuela et al., 2013b)

- Pyrolysis condition was grouped in three categories: (1) fast, (2) slow, (3) hydrochar (Cayuela et al., 2013b) 
- The residence time of biochar in soil was divided into different sub-groups including $\leq 1$ week ( $<8$ days), $\leq 1$ month ( $<31$ days), 3 months ( $<91$ days), 6 months $(<181$ days $), \leq 1$ year $(<366$ days), $>1$ year (>366) (Cayuela et al., 2013b).

- $\mathrm{N}$ fertilisation with biochar was grouped in five categories: (1) organic (slurry, manure, greenwaste compost, and urine), (2) urea, (3) ammonium nitrate $\left(\mathrm{NH}_{4} \mathrm{NO}_{3}\right)$, (4) $\mathrm{NO}_{3}$-based, and (5) $\mathrm{NH}_{4}$-based.

- Soil texture was grouped in three categories: (1) coarse (sandy loam, sandy clay loam, loamy sand), (2) medium (clay loam, loam, silty clay loam, silt, silt loam) or (3) fine (clay, silt clay, sandy clay) (Cayuela et al., 2013b)

- Soil pH was grouped in three categories: (1) Very acidic $(\mathrm{pH}<5)$, (2) Acidic $(5<\mathrm{pH}<6)$, and (3) Neutral (pH>6) (Jeffery et al., 2011).

- Crop types were grouped in five categories: (1) dried crop (maize, wheat, spring barley, lettuce, macadamia, and plantain), (2) grass (ryegrass, and fescue), (3) legumes (clover, bean, and peanut), (4) paddy rice, and (5) no crop.

The effect sizes of each group were calculated using a categorical random effects model, where the effect size was weighted in inverse proportion to its variance (Adams et al., 1997). Mean effect sizes of each category and the $95 \%$ confidence intervals (CIs) generated by bootstrapping (999 iterations) were calculated with MetaWin Version 2 Statistical software (Rosenberg et al., 2000). A threshold was set for weight to avoid skewing of the results due to a few cases with very low variance (very high weight). We ranked the weight of each case and then plotted the weight against the rank. The threshold of weight was determined as the tipping point at which the weight started to increase dramatically against rank (Fig. S5). All cases with weight larger than the threshold were reset as the threshold value and used in the meta-analysis. The effect sizes were converted to $\%$ change by the following equation: 
$\%$ change $=\left(\mathrm{e}^{\ln R R}-1\right) * 100($ Cayuela et al., 2013b) $(3)$

Mean effect sizes were considered significantly different from zero if the $95 \%$ CIs did not overlap zero, and significantly different from one another if their $95 \%$ CIs did not overlap. The mean of all effect sizes combined was calculated for $\mathrm{NH}_{4}{ }^{+}-\mathrm{N}$ and $\mathrm{NO}_{3}{ }^{-}-\mathrm{N}$.

To test the effects of publication bias (Rothstein et al., 2006) and the robustness of the meta-analysis, the funnel plot statistics and Fail-safe N technique (Rosenthal \& Rosnow, 1984) were used. Fail-safe $\mathrm{N}$ was used only when funnel plot statistics (Kendall's Tau and Spearman Rank-Order Correlation) were significant $(p<0.05)$. The Fail-safe number was compared with $5 n+1$ ( $n$ is the number of cases). To test the heterogeneity between groups, $\mathrm{Q}_{\text {between groups }} / \mathrm{Q}_{\text {total }}$ and $\mathrm{P}$ value of the random effect model were used when releasing the plots (Borenstein et al., 2009).

\subsubsection{Boosted regression tree analysis}

An additional boosted regression tree (BRT) analysis was performed to rank the importance of the explanatory variables and address non-linearity and factor interactions (Elith et al., 2008). The combination between BRT and mixed-effect model has been used in a number of meta-analyses (Rose et al., 2014; Zhang et al., 2015; Nguyen et al., 2016).

We performed a BRT analysis using the $\mathrm{R}$ package gbm combined with the dismo package (Ridgeway, 2013; Elith \& Leathwick, 2016). A Gaussian error structure was assumed during a 10fold cross-validation to estimate the optimal number of trees. To find the optimal setting, learning rate $(0.01,0.005,0.001)$ and bagging fraction $(0.5,0.6,0.75)$ were systematically altered to assess potential improvements to model fits. Among the fitted models, we found that the best model had a cross-validation deviance of $0.271( \pm 0.022)$ for $\mathrm{NH}_{4}{ }^{+}-\mathrm{N}$ and $0.248( \pm 0.042)$ for $\mathrm{NO}_{3}{ }^{-}-\mathrm{N}$ from a learning rate of 0.01 , bag fraction of 0.75 , and 10 -fold cross-validation. Tree complexity was set to 5 to address factor interactions (Elith et al., 2008).

\subsection{Results}




\subsubsection{General trend}

Our meta-analyses showed that biochar generally reduced soil mineral $\mathrm{N}$ by over $10 \%$ (Fig 2). In particular $\mathrm{NH}_{4}{ }^{+}-\mathrm{N}$ was reduced by $11 \pm 2 \%$ and $\mathrm{NO}_{3}{ }^{-}-\mathrm{N}$ by $10 \pm 1.6 \%$ regardless of experimental designs, biochar characteristics and time since application. The interactions between biochar and environmental factors (e.g. fertilisation, soil $\mathrm{pH}$, application rates, and residence time of biochar in soil) best explained SIN changes (Table 2). Among factors related to biochar properties, pyrolysis temperature explained SIN the most (Table 2).

Heterogeneity was detected in most analyses of this meta-analysis. This was inevitable because this meta-analysis included the data from a variety of experiment designs, biochar characteristics, soil properties, climate conditions, and crop types. Publication bias did not affect the trend of the plots, suggesting that the results were reliable (Table 1).

\subsubsection{Influence of biochar properties on SIN}

Soil $\mathrm{NH}_{4}{ }^{+}-\mathrm{N}$ was reduced the least in wood and the most in carbohydrate-based biochars (Fig. 3a). $\mathrm{NO}_{3}{ }^{-}-\mathrm{N}$ were reduced more by both carbohydrate and lignocellulosic-based biochars than other feedstocks (Fig 3b). Manure biochar interestingly did not have a significant effect on SIN.

Soil $\mathrm{NH}_{4}{ }^{+}-\mathrm{N}$ was decreased in high and low highest treatment temperature $(\mathrm{HTT})$ biochars $(<401$ and $\left.>600^{\circ} \mathrm{C}\right)$ (Fig. 4a). $\mathrm{NO}_{3}{ }^{-}-\mathrm{N}$ was decreased by low HTT biochar $\left(<401^{\circ} \mathrm{C}\right)($ Fig. $4 \mathrm{~b})$.

Hydrochar dramatically decreased $\mathrm{NH}_{4}{ }^{+}-\mathrm{N}(-46 \pm 7 \%)$ whereas fast pyrolysed biochar showed no significant effect on $\mathrm{NH}_{4}{ }^{+}-\mathrm{N}$ (Fig. 5a). All biochar types significantly reduced soil $\mathrm{NO}_{3}{ }^{-}-\mathrm{N}$ but there was no significant difference among types (Fig. 5b).

Only $39 \%$ of cases reported the value of biochar BET surface area, $11 \%$ of cases reported the value of biochar VOCs, and $47 \%$ of studies reported biochar CEC while methodologies for CEC determination varied between studies. The BRT model suggested that high CEC biochar reduced 
more soil $\mathrm{NH}_{4}{ }^{+}-\mathrm{N}$, and high BET surface area biochar reduced more SIN (Fig. 12). At concentrations of higher than $18 \%$, VOCs reduced more soil $\mathrm{NO}_{3}{ }^{-} \mathrm{-N}$ (Fig. 12i,k).

3.2.3. Influence of the interactions between biochar and environmental factors on SIN

Between the high rate biochar applications $(2-5 \%$ and $5-10 \%)$ and low rate biochar applications $(<1$ and 1-2\%), the high rate biochar applications caused the higher reduction of $\mathrm{NH}_{4}{ }^{+}-\mathrm{N}$ but this was not the case for $\mathrm{NO}_{3}{ }^{-}-\mathrm{N}$ (Fig. 6b). Most studies used an application rate $<5 \%$ while higher application rates were less common. The data on the rate $>10 \%$ was very limited (six cases) and could not be used to provide a reliable conclusion.

Biochar greatly reduced $\mathrm{NH}_{4}^{+}-\mathrm{N}$ one month after application $(-24 \pm 4 \%)$ whereas no significant change of $\mathrm{NH}_{4}{ }^{+}-\mathrm{N}$ was observed for longer residence times of biochar in soil up to 1 year (Fig. 7a). Interestingly, different time intervals did not affect $\mathrm{NO}_{3}{ }^{-}-\mathrm{N}$ since there was no significant difference in $\mathrm{NO}_{3}{ }^{-} \mathrm{N}$ content during the time (Fig. 7b). However, biochar significantly reduced $\mathrm{NO}_{3}{ }^{-}-\mathrm{N}^{-}$at all time intervals except $\leq 1$ year.

Biochar combined with urea, $\mathrm{NH}_{4}{ }^{+}$-based and $\mathrm{NH}_{4} \mathrm{NO}_{3}$ fertiliser reduced $\mathrm{NH}_{4}{ }^{+}-\mathrm{N}$ significantly, but biochar with organic fertiliser had no change on $\mathrm{NH}_{4}{ }^{+}-\mathrm{N}$ (Fig. 8a). Biochar with urea increased $\mathrm{NO}_{3}{ }^{-}-$ $\mathrm{N}$ but it decreased $\mathrm{NO}_{3}{ }^{-}-\mathrm{N}$ if it was combined with $\mathrm{NH}_{4} \mathrm{NO}_{3}$ and organic-based fertilisers (Fig. 8b). Biochar alone reduced both form of SIN.

Biochar application reduced the $\mathrm{NH}_{4}{ }^{+}-\mathrm{N}$ content in coarse soils to a greater extent than in mediumtextured soils (Fig. 9). Biochar also reduced more $\mathrm{NH}_{4}{ }^{+}-\mathrm{N}$ in acid groups than in the neutral group (Fig. 10a). $\mathrm{NO}_{3}{ }^{-} \mathrm{N}$ decreased with the increase of soil $\mathrm{pH}$ under biochar effects (Fig. 10b).

Biochar reduced soil $\mathrm{NH}_{4}{ }^{+}-\mathrm{N}$ in dried crop or without any crop (Fig. 11a). A significant decline in $\mathrm{NH}_{4}{ }^{+}-\mathrm{N}$ was also found in pot-based experiments (Fig. S3). The effects of biochar on $\mathrm{NO}_{3}{ }^{-}-\mathrm{N}$ were similar in different crop types and experimental designs (Fig. 11b, S2b). The number of paddy rice cases were limited ( $<10$ cases), therefore paddy rice was excluded from the figures. 


\subsection{Discussion}

The most noticeable findings are (1) the overall reduction of approximately $10 \%$ of SIN after biochar addition regardless of experimental conditions. However, the studies used to investigate biochar applications on SIN have been mainly undertaken within the first year following the biochar application (with only 42 out of 917 cases recorded after one year); (2) The interactions between biochar and environmental factors (e.g. fertilisation, soil $\mathrm{pH}$, application rates, and residence time of biochar in soil), and pyrolysis temperature best explained SIN changes; (3) woody biochar did not decrease SIN as much as other biochars produced from different feedstocks; and (4) the effects of biochar on SIN were strongly affected by fertiliser type; biochar applied with $\mathrm{NH}_{4}$-based fertilisers interestingly reduced soil $\mathrm{NH}_{4}{ }^{+}-\mathrm{N}$ the most, while biochar with organic fertiliser reduced soil $\mathrm{NO}_{3}{ }^{-} \mathrm{N}$ the most.

The overall reduction of SIN by biochar is concordant with the literature since biochar has been proven to reduce $\mathrm{N}$ availability as the result of high biochar $\mathrm{C}: \mathrm{N}$ ( $\mathrm{N}$ immobilisation) and high surface area (adsorption) (Lehmann et al., 2003; DeLuca et al., 2015). Two main implications of this reduction are (1) decrease of SIN leaching, and (2) reduced SIN availability for crops. Hence, SIN reduction may lead to reduced $\mathrm{N}$ uptake of plants in the short term after biochar application, but over the long term, available $\mathrm{N}$ may increase resulting in the increase of the overall crop yield (Biederman \& Harpole, 2013; Bai et al., 2015a; Bai et al., 2015b). For example, there are reports of increased $\mathrm{NO}_{3}{ }^{-}-\mathrm{N}$ and $\mathrm{NH}_{4}{ }^{+}-\mathrm{N}$ after 1, 2 and 10 years following biochar application (Bai et al., 2015a; Zhao et al., 2015; Hosseini Bai et al., 2016). In another study, $\mathrm{NH}_{4}{ }^{+}-\mathrm{N}$ and $\mathrm{NO}_{3}{ }^{-} \mathrm{N}$ did not differ between control and biochar (greenwaste and poultry biochar) plots, 5 years following biochar application (Bai et al., 2015b). It has also been reported that biochar is able to release immobilised N slowly over time to be assimilated by plants (Taghizadeh-Toosi et al., 2012b). This slow released $\mathrm{N}$ can offset the fertiliser inputs over time (Taghizadeh-Toosi et al., 2012b).

3.3.1. The effects of biochar properties on $\mathrm{N}$ availability 
Greater reduction of SIN was observed when biochars were produced from carbohydrate, in low HTT, and hydrothermal conditions (i.e. hydrochar) compared to other biochars. Labile C content was higher in hydrochar, carbohydrate and low HTT biochar (Downie et al., 2009; Malghani et al., 2013; Singh \& Cowie, 2014); also functional groups were higher in low HTT biochar than other biochars. Therefore, among biochar properties, pyrolysis temperature and surface properties of biochar are important factors influencing SIN.

Carbohydrates followed by lignocellulosic waste biochar decreased $\mathrm{N}$ the most because they had higher labile $\mathrm{C}$ as a food source for microbes than other biochars, leading to increased $\mathrm{N}$ immobilisation (Hilscher et al., 2009; Knicker, 2010). Also, the majority of carbohydrates groups were hydrochar which may have influenced on their effects. Hydrochar has lower carbonisation, higher $\mathrm{H} / \mathrm{C}$ and $\mathrm{O} / \mathrm{C}$ ratios, and higher concentration of easily degradable $\mathrm{C}$ compounds than biochar (Liu et al., 2010b; Qayyum et al., 2012; Bai et al., 2013). For example, dissolved organic C (DOC) contents of hydrochar and biochar produced at $\leq 500^{\circ} \mathrm{C}$ from corn silage are 12.99 and $0.033 \mathrm{mg} \mathrm{g}^{-1}$, respectively (Malghani et al., 2013); DOC of hydrochar and biochar produced at $190^{\circ} \mathrm{C}$ from spent brewer's grains are 54.969 and $0.016 \mathrm{mg} \mathrm{g}^{-1}$, respectively; from beetroot chips are 15.548 and $0.1 \mathrm{mg}$ $\mathrm{g}^{-1}$, respectively (Bargmann et al., 2014).

Noticeably, the least decrease of SIN was found for woody biochar as woody biochar had lower CEC, acid functional groups, and lower labile $\mathrm{C}$ compounds than crop-derived and herbaceous biochars, leading to lower N immobilisation and N chemisorption (Brewer et al., 2011; Harvey et al., 2012; Wang et al., 2015). Despite the fact that woody biochar had a high C:N ratio, $\mathrm{N}$ immobilisation rate depended on the portions of easily mineralisable $\mathrm{C}$ and biological recalcitrant $\mathrm{C}$ in biochars (Chan \& Xu, 2009); whereas woody biochar contains less degradable C than other biochars (Nelissen et al., 2015; Wang et al., 2015). For example, labile $\mathrm{C}$ content $\left(\mathrm{g} \mathrm{kg}^{-1} \mathrm{C}\right)$ of biochars produced at $400^{\circ} \mathrm{C}$ could be ranked in the order of wood biochar $(2.6)<$ leaf biochar $(6.2)<$ cow manure $(18.3)<$ poultry litter (32); produced at $550^{\circ} \mathrm{C}$ followed the same order of wood, leaf, cow manure, and 
poultry manure $(1.3,3.0,4.9,6.7$, respectively) (Singh \& Cowie, 2014). In our database, the averages CEC of herbaceous and lignocellulosic biochar (37.59 and $34.66 \mathrm{cmol} \mathrm{kg}^{-1}$, respectively) were also higher than that of woody biochar $\left(23.48 \mathrm{cmol} \mathrm{kg}^{-1}\right)$. Our BRT model also supported the significant correlation between biochar CEC and $\mathrm{NH}_{4}{ }^{+}-\mathrm{N}$ adsorption (Fig. 12).

More SIN was decreased in low HTT biochar $\left(\leq 400^{\circ} \mathrm{C}\right)$ than in other biochars. At low temperatures, acid functional groups, some labile $\mathrm{C}$ and bio-oils remained on the biochar surface and enhanced $\mathrm{N}$ adsorption and $\mathrm{N}$ immobilisation (Downie et al., 2009; Anderson et al., 2011; Gai et al., 2014; DeLuca et al., 2015; Whitman et al., 2015). High HTT biochar $\left(>600^{\circ} \mathrm{C}\right)$ reduced more $\mathrm{NH}_{4}{ }^{+}-\mathrm{N}$ by physisorption and $\mathrm{NO}_{3}{ }^{-}-\mathrm{N}$ by chemisorption (Downie et al., 2009; Kameyama et al., 2012; Clough et al., 2013). Our BRT model showed significant correlation between biochar BET surface area and SIN (Fig. 12).

3.3.2. The interaction between biochar and environmental factors

Our study indicated that biochar decreased SIN when it stayed in soil for a short term $(<1$ month), was applied at high rate $(\geq 2 \%)$, and in coarse-textured soil. $\mathrm{NH}_{4}{ }^{+}-\mathrm{N}$ also declined more in biocharinorganic $\mathrm{N}$ fertiliser combination and acidic soil. $\mathrm{NO}_{3}{ }^{-} \mathrm{N}$ was reduced more if biochar was applied alone, with organic fertiliser, and in neutral soil.

The reduction of SIN by increased biochar application rate may be due to higher adsorption and $\mathrm{N}$ immobilisation. A short time after biochar application (up to one month), $\mathrm{N}$ immobilisation and adsorption was boosted because soil $\mathrm{C}: \mathrm{N}$ ratio and biochar adsorption surface were enhanced. (Rondon et al., 2007; Downie et al., 2009; Hammes \& Schmidt, 2009; Xu et al., 2015). Multicollinearity was detected between biochar rate, feedstock type, pyrolysis temperature, and biochar BET surface area moderating $\mathrm{NO}_{3}{ }^{-} \mathrm{N}$ (Table 3, S2). Most biochars in the high application rate groups were produced from high carbohydrate feedstocks, with low HTT and a high BET area which explained $\mathrm{NO}_{3}{ }^{-}-\mathrm{N}$ reductions (Fig. 3b, 4b, 12). This multicollinearity contributed to a greater 
$\mathrm{NO}_{3}{ }^{-}-\mathrm{N}$ reduction in biochar applied at high rates. In contrast, low rate groups contained $89 \%$ cases with manure biochars, high HTT and low BET area which did not result in decreased $\mathrm{NO}_{3}{ }^{-}-\mathrm{N}^{-} \mathrm{NO}_{3}{ }^{-}-$ $\mathrm{N}$ reduction depended on both the biochar application rate and also the feedstock type and pyrolysis temperature. Such multicollinearity was not observed for $\mathrm{NH}_{4}{ }^{+}-\mathrm{N}$.

Over longer residence times, $\mathrm{N}$ immobilisation was reduced due to decreased labile organic compounds and adsorption capacities of biochar when organic and mineral compounds built up on biochar surface (Pignatello et al., 2006; Cheng et al., 2008; McLaughlin et al., 2009; Joseph et al., 2010; Singh \& Cowie, 2014). A negative priming effect (decrease of mineralisation) was also observed in the long term ( $>250$ days) (Zimmerman et al., 2011). The long-term reduction of $\mathrm{NO}_{3}{ }^{-} \mathrm{N}$ might be due to leaching but the mechanism remained unclear (Ventura et al., 2013). Long-term effects of biochar were a shortcoming of this meta-analysis because the studies of long-term biochar were limited (Table 4).

Our study suggested that fertiliser type added to biochar is also a crucial factor affecting SIN. We found that (1) adding organic fertiliser to biochar only reduced $\mathrm{NO}_{3}{ }^{-} \mathrm{N}$; (2) adding urea and $\mathrm{NH}_{4} \mathrm{NO}_{3}$ fertiliser to biochar increased and decreased $\mathrm{NO}_{3}{ }^{-}-\mathrm{N}$ respectively, (3) adding inorganic $\mathrm{N}$ fertilisers to biochar reduced soil $\mathrm{NH}_{4}{ }^{+}-\mathrm{N}$, and (4) without fertiliser, biochar significantly reduced $\mathrm{NO}_{3}{ }^{-}-\mathrm{N}$. CEC in biochar-amended soil was enhanced when organic fertiliser was co-applied because organic fertiliser also contributed to increase $\mathrm{SOM}$; so more soil $\mathrm{NH}_{4}{ }^{+}-\mathrm{N}$ was adsorbed and the $\mathrm{NH}_{4}{ }^{+}-\mathrm{N}$ pool for nitrification declined (Ulyett et al., 2014). Our result was contradictory with van Zwieten et al. (2013) who observed increased $\mathrm{NO}_{3}{ }^{-}-\mathrm{N}$ after poultry litter biochar and organic amendment addition because organic amendments (poultry litter) promoted $\mathrm{N}$ mineralisation within a short period of time following biochar application (7-35 days), leading to an increase in SIN (van Zwieten et al., 2013). Biochar alone (unfertilised) significantly reduced $\mathrm{NO}_{3}{ }^{-}-\mathrm{N}$ possibly due to adsorption and immobilisation (please see 2.1, 2.2.2). Also, it should be noted that most biochars in the unfertilised group were applied at high rates $(\geq 2 \%)$ and in neutral soil, which reduced $\mathrm{NO}_{3}{ }^{-} \mathrm{N}$ the most (Fig. 6b, 
10b). Therefore, this multicollinearity contributed to extending $\mathrm{NO}_{3}{ }^{-}-\mathrm{N}$ reduction in unfertilised groups in our database. $\mathrm{NO}_{3}{ }^{-} \mathrm{N}$ increase by biochar and urea combinations may be associated with nitrification stimulation due to increased substrates for nitrifiers (van Zwieten et al., 2013; Shen et al., 2014). Biochar co-applied with $\mathrm{NH}_{4} \mathrm{NO}_{3}$ and $\mathrm{NH}_{4}{ }^{+}$-based fertiliser did not show the obvious effect on soil $\mathrm{NO}_{3}{ }^{-} \mathrm{N}$ as much as urea because the application rate of urea was higher than that of $\mathrm{NH}_{4} \mathrm{NO}_{3}$ and $\mathrm{NH}_{4}{ }^{+}$-based fertiliser. Alburquerque et al. (2013) also found that adding $\mathrm{NH}_{4} \mathrm{NO}_{3}$ fertilisation to biochar increased soil $\mathrm{NO}_{3}{ }^{-} \mathrm{N}$ at high rates compared to low rates (58 vs $144 \mathrm{~mL}$ per pot) when fertiliser was applied in biochar rates of $\leq 1 \%$, suggesting that the high rate of fertiliser may be necessary to stimulate nitrification significantly when it is combined with biochar (Alburquerque et al., 2013).

In the presence of inorganic fertiliser, biochar reduced $\mathrm{NH}_{4}{ }^{+}-\mathrm{N}$, perhaps due to adsorption equilibrium and nitrification (Bohn et al., 2002), as supported by the BRT model that fertiliser type interacted with biochar $\mathrm{CEC}$ and soil $\mathrm{pH}$. The multicollinearity between type of fertiliser, biochar feedstock and residence time of biochar in soil might mask the effect of biochar alone on soil $\mathrm{NH}_{4}{ }^{+}$ $\mathrm{N}$. Most of the cases in our unfertilised group used manure biochar and stayed in soil for more than one month, which had no effect on $\mathrm{NH}_{4}{ }^{+}-\mathrm{N}$ (Fig. 3a, 7a).

Our study indicated that biochar application decreased $\mathrm{NH}_{4}{ }^{+}-\mathrm{N}$ in coarse soils more than in other soil texture types, but soil texture did not moderate the effects of biochar on soil $\mathrm{NO}_{3}{ }^{-}-\mathrm{N}$. This is possibly attributed to volatilisation of $\mathrm{NH}_{3}$ because $90 \%$ of cases in the coarse group had acidic soil $\mathrm{pH}$, whereas biochar increased $\mathrm{NH}_{3}$ volatilisation by elevating soil $\mathrm{pH}$ (Clough et al., 2013). The BRT model supported this by showing the interaction between soil $\mathrm{pH}$ and soil texture (Table S1). Although the literature has shown that biochar could reduce $\mathrm{NH}_{3}$ emission if biochar is combined with organic fertiliser or during composting (Clough et al., 2013), our meta-analysis did not include any case of biochar-organic fertilisation within the coarse group due to the lack of data. 
Our results indicated that biochar only increased $\mathrm{NO}_{3}{ }^{-} \mathrm{N}$ significantly in very acidic soils $(\mathrm{pH}<5)$ probably by increased nitrification and decreased denitrification due to the biochar liming effect (Cayuela et al., 2013b). Adding biochar to acidic or very acidic soil has been shown to have a greater liming effects in soil leading to affect SIN compared to those applied in neutral or calcareous soil where the activity of nitrifiers is high and nitrification inhibitors are naturally lacking (Lehmann et al., 2003; Rondon et al., 2007; Clough \& Condron, 2010; Zhao et al., 2014). Moreover, as shown by the BRT model, biochar reduced $\mathrm{NO}_{3}{ }^{-} \mathrm{N}$ the most in neutral soil because there was multicollinearity in our meta-analysis between soil $\mathrm{pH}$, pyrolysis temperature and biochar rate (Table 3, S2). 67\% and $73 \%$ of the cases in the neutral group were biochar produced at $\leq 400^{\circ} \mathrm{C}$ and applied at $\geq 2 \%$, respectively, which have been shown to reduce the most $\mathrm{NO}_{3}{ }^{-} \mathrm{N}$ (Fig. 4b, 6b). Regarding nitrification, our BRT model also confirmed that biochar with high concentration of VOCs reduced more soil $\mathrm{NO}_{3}{ }^{-}-\mathrm{N}$ since VOCs have been reported to be nitrifier inhibitors (please see 2.2.3).

Biochar significantly reduced SIN in both unplanted and planted systems with an exception observed for legumes (Fig. 11). The negative effects of plants on SIN were perhaps due to increased uptake of SIN by plants when biochars were applied (Chan et al., 2008). It was likely that no effect of biochar on $\mathrm{NH}_{4}{ }^{+}-\mathrm{N}$ in grass was associated with the interaction between crop type, fertiliser, and pyrolysis temperature in our meta-analysis data. Biochars in $83 \%$ and $72 \%$ cases of grass group were applied with organic fertiliser and produced at mid-range temperature, respectively, which had no effect or little negative effect on soil $\mathrm{NH}_{4}{ }^{+}-\mathrm{N}$ (Fig. 4a, 8a). No effect by legumes on SIN was possibly because the positive effects of biochar on SIN by fixation (Clough et al., 2013; Quilliam et al., 2013; Thies et al., 2015; Xu et al., 2015) hindered the negative effects of biochar on SIN. Legumes contributed to increased $\mathrm{N}$ in soil leading to confounded effects of decreased SIN after biochar application. In unplanted systems, however, SIN was reduced mainly by adsorption and immobilisation as reported by the literature in our meta-analysis (Zavalloni et al., 2011; Zheng et al., 2012; Ducey et al., 2013), and volatilisation when soil pH was increased by the biochar liming effect (Bargmann et al., 2014). 
The effects of biochar on soil $\mathrm{NH}_{4}{ }^{+}-\mathrm{N}$ in pot-based trials can over-estimate the field-based results as suggested by different meta-analyses (Jeffery et al., 2011; Liu et al., 2013). We also found a strong confounding effect between pot and field experiments. In our meta-analysis database, $83 \%$ of field trials focused on longer term effects of biochar ( $>1$ month) in soil, while $69 \%$ of pot trials investigated short term effects $\left(\leq 1\right.$ month). Therefore, it is not possible to conclude $\mathrm{NH}_{4}{ }^{+}-\mathrm{N}$ was reduced more in pot trials on the basis of this analysis. Further studies are needed to test the combined effects of experimental design and residence time of biochar in soil.

\section{Conclusion and perspective}

This meta-analysis showed an overall negative, statistically significant but moderate effects of biochar application on SIN (approximately $-11 \pm 2 \%$ of $\mathrm{NH}_{4}{ }^{+}-\mathrm{N}$ and $-10 \pm 1.6 \% \mathrm{NO}_{3}{ }^{-}-\mathrm{N}$ ). The $\mathrm{N}$ cycling in soils amended with biochar is potentially complex because of the diverse properties of biochars and soils as well as the interactions between them. This highlights the need for further longterm experiments that quantify the effects of factor combination (e.g. fertiliser type and biochar application rate, soil $\mathrm{pH}$ and biochar application rate, feedstock type and biochar application rate, etc.) on SIN.

Some other recommendations need to be considered when applying biochar into soil (i) woody biochar can be applied for less reduction of $\mathrm{N}$ in soil; (ii) carbohydrate biochar should be combined with organic fertiliser to offset the decreases of SIN; (iii) biochar should be applied at least one month prior to planting to the soil so plants do not suffer decreased $\mathrm{N}$ within the first month; and (iv) hydrochar and high rate biochar application could be combined with organic fertiliser to offset the effect of $\mathrm{N}$ immobilisation via stimulation of $\mathrm{N}$ mineralisation. Recently developed enhanced (organo-mineral) biochar, a low-dose, high-efficiency biochar-fertiliser product, may also offset the reduction caused by conventional biochar application (Joseph et al., 2013; Darby et al., 2016; Ye et al., 2016). Enhanced biochar is produced by torrefaction of the mixture between biochar and other materials (e.g. clay, ground rock, minerals); pre-pyrolysis (i.e. slow-pyrolysing feedstock with 
minerals and nutrients at low temperature $350-450^{\circ} \mathrm{C}$ ), post-pyrolysis (i.e. mixture of biochar and minerals/nutrients/manures is treated with heat or chemicals), and composting biochar with organic materials (Joseph et al., 2013; Lin et al., 2013). Application of enhanced biochar to soils can reduce the fertiliser input, be a better slow-released fertiliser for plants than other biochar products, increase disease resistance, germination rates, and nutrient uptake of plants, and reduce $\mathrm{N}$ leaching (Joseph et al., 2013; Lin et al., 2013; Chia et al., 2014; Darby et al., 2016).

This meta-analysis identified factors influencing SIN after biochar application including residence time of biochar in soil, fertilisation, soil properties (texture and $\mathrm{pH}$ ), biochar application rate, feedstock, temperature and type of pyrolysis, BET surface, CEC, and VOCs content of biochar. However, the influence of other potentially crucial factors could not be considered due to a lack of auxiliary data including pyrolysis time interval of biochar production, biochar activation type, electrical conductivity (EC) of biochar, the size of biochar particles in biochar treatments, $\mathrm{C}: \mathrm{N}$ ratio of organic fertiliser combined with biochar, and SOM content. This issue led to reduction of the number of studies that could be included in this analysis. Long term studies ( $>5$ years) have not been tested in our met-analysis due to limited number of studies. These shortcomings of this meta-analysis were summarised in Table 3.

In brief, the future studies on biochar and SIN should focus on a mechanistic understanding of the interactions of biochar in soil. Some basic information should be reported when a study is published including (i) production conditions (activation type, atmospheric pressure, feedstock properties e.g. origin, elemental analysis), (ii) biochar properties (CEC, surface area, particle size, EC, adsorption capacity), and (iii) environmental conditions and soil management (meteorological data, tillage, cultivation, crop type).

\section{Acknowledgements}


We would like to acknowledge the work carried out by the researchers whose published data was used for this meta-analysis. This study was supported with Seed Funding from University of the Sunshine Coast and Griffith University. Ms. TT Nhan Nguyen received a VIED scholarship from the Vietnamese Government. We would like to thank anonymous reviewers for valuable suggestions to improve the presentation of this meta-analysis.

\section{Appendix A. Supplementary data}

Supplementary data associated with this article can be found in the online version.

\section{References}

Adams, D. C.;Gurevitch, J., \& Rosenberg, M. S., 1997. Resampling tests for meta-analysis of ecological data. Ecology, 78(4), 1277-1283. doi: 10.1890/00129658(1997)078[1277:RTFMAO]2.0.CO;2

Alburquerque, J. A.;Salazar, P.;Barrón, V.;Torrent, J.;Campillo, M. d. C. d.;Gallardo, A., \& Villar, R., 2013. Enhanced wheat yield by biochar addition under different mineral fertilization levels. Agron. Sustain. Dev., 33, 475-484.

Ameloot, N.;Graber, E. R.;Verheijen, F. G. A., \& De Neve, S., 2013. Interactions between biochar stability and soil organisms: review and research needs. Eur. J. Soil Sci., 64(4), 379-390. doi: 10.1111/ejss. 12064

Amonette, J. E., \& Joseph, S., 2009. Characteristics of Biochar: Microchemical Properties. In J. Lehmann \& S. Joseph (Eds.), Biochar for Environmental Management: Science and Technology (1 ed., pp. 33-52). London: UK: Earthscan.

Anderson, C. R.;Condron, L. M.;Clough, T. J.;Fiers, M.;Stewart, A.;Hill, R. A., \& Sherlock, R. R., 2011. Biochar induced soil microbial community change: Implications for biogeochemical cycling of carbon, nitrogen and phosphorus. Pedobiologia, 54(5-6), 309-320. doi: 10.1016/j.pedobi.2011.07.005 
Atkinson, C. J.;Fitzgerald, J. D., \& Hipps, N. A., 2010. Potential mechanisms for achieving agricultural benefits from biochar application to temperate soils: a review. Plant Soil, 337, 118.

Augusto, L.;Badeau, V.;Arrouays, D.;Trichet, P.;Flot, J. L.;Jolivet, C., \& Merzeau, e. D., 2006. Caractérisation physico-chimique des sols à l'échelle d'une région naturelle à partir d'une compilation de données-Exemple des sols du massif forestier landais. Etud. Gest. Sols, 13(1), 7-22.

Bai, M.;Wilske, B.;Buegger, F.;Esperschütz, J.;Kammann, C. I.;Eckhardt, C.;Koestler, M.;Kraft, P.;Bach, M.;Frede, H.-G., \& Breuer, L., 2013. Degradation kinetics of biochar from pyrolysis and hydrothermal carbonization in temperate soils. Plant Soil, 372(1), 375-387.

Bai, S. H.;Blumfield, T. J.;Xu, Z.;Chen, C., \& Wild, C., 2012. Soil organic matter dynamics and nitrogen availability in response to site preparation and management during revegetation in tropical Central Queensland, Australia. J Soils Sediments, 12, 386-395.

Bai, S. H.;Reverchon, F.;Xu, C. Y.;Xu, Z.;Blumfield, T. J.;Zhao, H.;van Zwieten, L., \& Wallace, H. M., 2015a. Wood biochar increases nitrogen retention in field settings mainly through abiotic processes. Soil Biol Biochem, 90, 232-240. doi: http://dx.doi.org/10.1016/j.soilbio.2015.08.007

Bai, S. H.;Xu, C.-Y.;Xu, Z.;Blumfield, T. J.;Zhao, H.;HelenWallace;Reverchon, F., \& Zwieten, L. V., 2015b. Soil and foliar nutrient and nitrogen isotope composition $\left(\delta^{15} \mathrm{~N}\right)$ at 5 years after poultry litter and green waste biochar amendment in a macadamia orchard. Environ Sci Pollut Res, 22, 3803-3809.

Bai, S. H.;Dempsey, R.;Reverchon, F.;Blumfield, T. J.;Ryan, S., \& Cernusak, L. A., 2016. Effects of forest thinning on soil-plant carbon and nitrogen dynamics. Plant Soil, 1-13.

Bakken, L. R.;Bergaust, L.;Liu, B., \& Frostegård, Å., 2012. Regulation of denitrification at the cellular level: a clue to the understanding of $\mathrm{N}_{2} \mathrm{O}$ emissions from soils. Philos Trans $R$ Soc Lond B Biol Sci, 367(1593), 1226-1234. doi: 10.1098/rstb.2011.0321 
Bargmann, I.;Martens, R.;Rillig, M. C.;Andrea Kruse, \& Kücke, M., 2014. Hydrochar amendment promotes microbial immobilization of mineral N. J. Plant Nutr. Soil Sci., 177, 59-67.

Berglund, L.;DeLuca, T., \& Zackrisson, O., 2004. Activated carbon amendments to soil alters nitrification rates in Scots pine forests. Soil Biol Biochem, 36(12), 2067-2073.

Biederman, L. A., \& Harpole, W. S., 2013. Biochar and its effects on plant productivity and nutrient cycling: a meta-analysis. GCB Bioenergy, 5(2), 202-214.

Blackwell, P.;Riethmuller, G., \& Collins, M., 2009. Biochar Application to Soil. In J. Lehmann \& S. Joseph (Eds.), Biochar for Environmental Management: Science and Technology (1 ed., pp. 207-226). London: UK: Earthscan.

Blagodatskaya, E.;Yuyukina, T.;Blagodatsky, S., \& Kuzyakov, Y., 2011. Turnover of soil organic matter and of microbial biomass under C 3-C 4 vegetation change: consideration of $13 \mathrm{C}$ fractionation and preferential substrate utilization. Soil Biol Biochem, 43(1), 159-166.

Bohn, H. L.;Myer, R. A., \& O'Connor, G. A., 2002. Soil Chemistry (2 ed.): Wiley.

Borenstein, M.;Hedges, L. V.;Higgins, J. P. T., \& Rothstein, H. R., 2009. Introduction to MetaAnalysis: John Wiley \& Sons, Ltd.

Boudsocq, S.;Abbadie, L.;Niboyet, A.;Barot, S.;Lata, J. C.;Raynaud, X.;Loeuille, N.;Mathieu, J., \& Blouin, M., 2012. Plant Preference for Ammonium versus Nitrate: A Neglected Determinant of Ecosystem Functioning? Am. Nat 180(1), 60-69.

Bradbury, N.;Whitmore, A.;Hart, P., \& Jenkinson, D., 1993. Modelling the fate of nitrogen in crop and soil in the years following application of 15 N-labelled fertilizer to winter wheat. J Agr Sci, 121(03), 363-379.

Brandstaka, T.;Helenius, J.;Hovi, J.;Kivelä, J.;Koppelmäki, K.;Simojoki, A.;Soinne, H., \& Tammeorg, P., 2010. Biochar filter: use of biochar in agriculture as soil conditioner. Report for BSAS Commitment 
Brennan, J. K.;Bandosz, T. J.;Thomson, K. T., \& Gubbins, K. E., 2001. Water in porous carbons. Colloids Surface A, 187-188, 539-568. doi: http://dx.doi.org/10.1016/S0927-7757(01)006446

Brewer, C. E.;Unger, R.;Schmidt-Rohr, K., \& Brown, R. C., 2011. Criteria to Select Biochars for Field Studies based on Biochar Chemical Properties. Bioenergy Res., 4(4), 312-323.

Brown, R. A.;Kercher, A. K.;Nguyen, T. H.;Nagle, D. C., \& Ball, W. P., 2006. Production and characterization of synthetic wood chars for use as surrogates for natural sorbents. Org Geochem, 37(3), 321-333.

Brunauer, S.;Emmett, P. H., \& Teller, E., 1938. Adsorption of gases in multimolecular layers. J Am Chem Soc, 60(2), 309-319.

Bruun, E. W.;Muller-Stover, D.;Ambus, P., \& Hauggaard-Nielsen, H., 2011. Application of biochar to soil and $\mathrm{N}_{2} \mathrm{O}$ emissions, potential effects of blending fast-pyrolysis biochar with anaerobically digested slurry. Eur. J. Soil Sci., 62, 581-589.

Bruun, E. W.;Ambus, P.;Egsgaard, H., \& Hauggaard-Nielsen, H., 2012. Effects of slow and fast pyrolysis biochar on soil C and N turnover dynamics. Soil Biol Biochem, 46, 73-79.

Cayuela, M. L.;Sanchez-Monedero, M. A.;Roig, A. n.;Hanley, K.;Enders, A., \& Lehmann, J., 2013 a. Biochar and denitrification in soils, when, how much and why does biochar reduce $\mathrm{N}_{2} \mathrm{O}$ emissions. Sci Rep., 3(1702), 1-7.

Cayuela, M. L.;Zwieten, L. v.;Singh, B. P.;Jeffery, S.;Roig, A., \& Sánchez-Monedero, M. A., $2013 b$. Biochar's role in mitigating soil nitrous oxide emissions: A review and meta-analysis. Agric Ecosyst Environ, 191, 5-16.

Chan, K. Y.;van Zwieten, L.;Meszaros, I.;Downie, A., \& Joseph, S., 2008. Using poultry litter biochars as soil amendments. Soil Res., 46(5), 437-444. doi:

http://dx.doi.org/10.1071/SR08036 
Chan, K. Y., \& Xu, Z., 2009. Biochar: Nutrient Properties and Their Enhancement. In J. Lehmann \& S. Joseph (Eds.), Biochar for Environmental Management: Science and Technology (Vol. 1, pp. 67-84). London: UK: Earthscan.

Cheng, C.-H.;Lehmann, J., \& Engelhard, M. H., 2008. Natural oxidation of black carbon in soils: Changes in molecular form and surface charge along a climosequence. Geochim. Cosmochim. Acta, 72(6), 1598-1610. doi: http://dx.doi.org/10.1016/j.gca.2008.01.010

Chenu, C.;Hassink, J., \& Bloem, J., 2001. Short-term changes in the spatial distribution of microorganisms in soil aggregates as affected by glucose addition. Biol. Fertil. Soils, 34(5), 349-356.

Chia, C. H.;Singh, B. P.;Joseph, S.;Graber, E. R., \& Munroe, P., 2014. Characterization of an enriched biochar. J. Anal. Appl. Pyrolysis, 108, 26-34.

Chun, Y.;Sheng, G.;Chiou, C. T., \& Xing, B., 2004. Compositions and Sorptive Properties of Crop Residue-Derived Chars. Environ Sci Technol, 38(17), 4649-4655. doi: 10.1021/es035034w

Clough, T.;Condron, L.;Kammann, C., \& Müller, C., 2013. A review of biochar and soil nitrogen dynamics. Agronomy, 3(2), 275-293.

Clough, T. J.;Bertram, J. E.;Ray, J. L.;Condron, L. M.;O’Callaghan, M.;Sherlock, R. R., \& Wells, N. S., 2010. Unweathered Wood Biochar Impact on Nitrous Oxide Emissions from a BovineUrine-Amended Pasture Soil. Soil Sci. Soc. Am. J., 74, 852-860.

Clough, T. J., \& Condron, L. M., 2010. Biochar and the nitrogen cycle: introduction. J Environ Qual, 39(4), 1218-1223. doi: 10.2134/jeq2010.0204

Darby, I.;Xu, C. Y.;Wallace, H. M.;Joseph, S.;Pace, B., \& Bai, S. H., 2016. Short-term dynamics of carbon and nitrogen using compost, compost-biochar mixture and organo-mineral biochar. Environ Sci Pollut Res Int, 23(11), 11267-11278. doi: 10.1007/s11356-016-6336-7

De Boer, W., \& Kowalchuk, G. A., 2001. Nitrification in acid soils: micro-organisms and mechanisms. Soil Biol Biochem, 33(7-8), 853-866. doi: http://dx.doi.org/10.1016/S00380717(00)00247-9 
Deenik, J. L.;McClellan, T.;Uehara, G.;Antal, M. J., \& Campbell, S., 2010. Charcoal Volatile Matter Content Influences Plant Growth and Soil Nitrogen Transformations. Soil Sci Soc Am J, 74(4), 1259-1270. doi: 10.2136/sssaj2009.0115

Delhaize, E., \& Ryan, P. R., 1995. Aluminum Toxicity and Tolerance in Plants. Plant Physiol., 107(2), 315-321.

DeLuca, T. H.;Gundale, M. J.;MacKenzie, M. D., \& Jones, D. L., 2015. Biochar effects on soil nutrient transformations. In J. Lehmann \& S. Joseph (Eds.), Biochar for Environmental Management: Science, Technology and Implementation (2 ed., pp. 421-454): Taylor \& Francis.

Dharmakeerthi, R. S.;Chandrasiri, J. A. S., \& Edirimanne, V. U., 2012. Effect of rubber wood biochar on nutrition and growth of nursery plants of Hevea brasiliensis established in an Ultisol. SpringerPlus, 1, 84.

Downie, A.; Crosky, A., \& Munroe, O., 2009. Chapter 2: Physical Properties of Biochar. In J. Lehmann \& J. Stephen (Eds.), Biochar for Environmental Management: Science and Technology (1 ed., pp. 13-32). London, UK: Earthscan.

Ducey, T. F.;Ippolito, J. A.;Cantrell, K. B.;Novak, J. M., \& Lentz, R. D., 2013. Addition of activated switchgrass biochar to an aridic subsoil increases microbial nitrogen cycling gene abundances. Appl Soil Ecol, 65, 65-72. doi: 10.1016/j.apsoil.2013.01.006

Elith, J.;Leathwick, J. R., \& Hastie, T., 2008. A working guide to boosted regression trees. J Anim Ecol, 77(4), 802-813.

Elith, J., \& Leathwick, J., 2016. Boosted Regression Trees for ecological modeling.

Gai, X.;Wang, H.;Liu, J.;Zhai, L.;Liu, S.;Ren, T., \& Liu, H., 2014. Effects of Feedstock and Pyrolysis Temperature on Biochar Adsorption of Ammonium and Nitrate. PLoS One, 9(12).

Gaskin, J. W.;Steiner, C.;Harris, K.;Das, K. C., \& Bibens, B., 2008. Effect of lowtemperature pyrolysis conditions on biochars for agricultural use. Trans ASAE (Am Soc Agric Eng), 51(6), 2061-2069. 
Giller, K. E., 2001. Nitrogen fixation in tropical cropping systems: Cabi.

Gundale, M. J., \& DeLuca, T. H., 2006. Temperature and source material influence ecological attributes of ponderosa pine and Douglas-fir charcoal. Forest Ecol Manag, 231(1), 86-93.

Hahne, K. S., \& Schuch, U. K., 2004. Response of Nitrate and Ammonium on Growth of Prosopis Velutina and Simmondsia Chinensis Seedlings (Vol. Turfgrass and Ornamental Research Report). University of Arizona, College of Agriculture University of Arizona, College of Agriculture

Hamer, U.;Marschner, B.;Brodowski, S., \& Amelung, W., 2004. Interactive priming effect of black carbon and glucose mineralisation. Org Geochem, 35, 823-830. doi:

10.1016/j.orggeochem.2004.03.003

Hammes, K., \& Schmidt, M. W. I., 2009. Changes of Biochar in Soil. In J. Lehmann \& J. Stephen (Eds.), Biochar for Environmental Management: Science and Technology (1 ed., pp. 169181). London, Uk: Earthscan.

Hart, S. C.;Stark, J. M.;Davidson, E. A., \& Firestone, M. K., 1994. Nitrogen mineralization, immobilization, and nitrification. Methods of Soil Analysis: Part 2-Microbiological and Biochemical Properties(methodsofsoilan2), 985-1018.

Harter, J.;Krause, H. M.;Schuettler, S.;Ruser, R.;Fromme, M.;Scholten, T.;Kappler, A., \& Behrens, S., 2014. Linking $\mathrm{N}_{2} \mathrm{O}$ emissions from biochar-amended soil to the structure and function of the N-cycling microbial community. ISME J., 8(3), 660-674. doi: 10.1038/ismej.2013.160

Harvey, O. R.;Herbert, B. E.;Kuo, L., \& Louchouarn, P., 2012. Generalized Two-Dimensional Perturbation Correlation Infrared Spectroscopy Reveals Mechanisms for the Development of Surface Charge and Recalcitrance in Plant-Derived Biochars. Environ Sci Technol, 46(19), 10641-10650. doi: 10.1021/es302971d

Heincke, M., \& Kaupenjohann, M., 1999. Effects of soil solution on the dynamics of $\mathrm{N}_{2} \mathrm{O}$ emissions: a review. Nutr Cycl Agroecosys, 55(2), 133-157. doi: 10.1023/A:1009842011599 
Hilscher, A.;Heister, K.;Siewert, C., \& Knicker, H., 2009. Mineralisation and structural changes during the initial phase of microbial degradation of pyrogenic plant residues in soil. Org Geochem, 40(3), 332-342. doi: http://dx.doi.org/10.1016/j.orggeochem.2008.12.004

Hosseini Bai, S.;Xu, C. Y.;Xu, Z. H.;Blumfield, T. J.;Wallace, H. M.;Walton, D. A.;Randall, B. W., \& Van Zwieten, L., 2016. Wood base biochar alters inorganic N. Acta Horticulturae (1109), 151-154. doi: 10.17660/ActaHortic.2016.1109.24

Huwaldt, J. A., 2012. Plot Digitizer (Version 2.6.2). Retrieved from http://plotdigitizer.sourceforge.net

Jeffery, S.;Verheijen, F. G. A.;van der Velde, M., \& Bastos, A. C., 2011. A quantitative review of the effects of biochar application to soils on crop productivity using meta-analysis. Agric Ecosyst Environ, 144(1), 175-187. doi: 10.1016/j.agee.2011.08.015

Jeffery, S.;Abalos, D.;Spokas, K. A., \& Verheijen, F. G. A., 2015. Biochar effects on crop yield. In L. Johannes \& J. Stephen (Eds.), Biochar for Environmental Management: Science, Technology and Implementation (2 ed.). London: Taylor \& Francis.

Joseph, S.;Peacocke, C.;Lehmann, J., \& Munroe, P., 2009. Developing a Biochar Classification and Test Methods. In J. Lehmann \& S. Joseph (Eds.), Biochar for Environmental Management: Science and Technology (1 ed., pp. 107-126). London: Earthscan.

Joseph, S.;Graber, E.;Chia, C.;Munroe, P.;Donne, S.;Thomas, T.;Nielsen, S.;Marjo, C.;Rutlidge, H.;Pan, G.;Li, L.;Taylor, P.;Rawal, A., \& Hook, J., 2013. Shifting paradigms: development of high-efficiency biochar fertilizers based on nano-structures and soluble components. Carbon Manag, 4(3), 323-343. doi: 10.4155/cmt.13.23

Joseph, S. D.;Camps-Arbestain, M.;Lin, Y.;Munroe, P.;Chia, C. H.;Hook, J.;Zwieten, L. v.;Kimber, S.;D, A. C.;Singh, B. P.;Lehmann, J.;Foidl, N.;Smernik, R. J., \& Amonette, J. E., 2010. An investigation into the reactions of biochar in soil. Aust. J. Soil Res., 48, 501-515. 
Kameyama, K.;Miyamoto, T.;Shiono, T., \& Shinogi, Y., 2012. Influence of Sugarcane Bagassederived Biochar Application on Nitrate Leaching in Calcaric Dark Red Soil. J Environ Qual, 41(4), 1131-1137. doi: 10.2134/jeq2010.0453

Kammann, C. I.;Schmidt, H.-P.;Messerschmidt, N.;Linsel, S.;Steffens, D.;Müller, C.;Koyro, H.W.;Conte, P., \& Stephen, J., 2015. Plant growth improvement mediated by nitrate capture in co-composted biochar. Sci Rep., 5, 11080. doi: 10.1038/srep11080

Knicker, H., 2010. "Black nitrogen" - an important fraction in determining the recalcitrance of charcoal. Org Geochem, 41(9), 947-950. doi: http://dx.doi.org/10.1016/j.orggeochem.2010.04.007

Kookana, R. S.;Sarmah, A. K.;Zwieten, L. V.;Krull, E., \& Singh, B., 2011. Biochar Application to Soil: Agronomic and Environmental Benefits and Unintended Consequences. In D. L. Sparks (Ed.), Advances in Agronomy (Vol. 112, pp. 103-143). USA: Academic Press.

Kurose, K.;Okamura, D., \& Yatagai, M., 2007. Composition of the essential oils from the leaves of nine Pinus species and the cones of three of Pinus species. Flavour Frag J, 22(1), 10-20. doi: 10.1002/ffj. 1609

Kuzyakov, Y.;Friedel, J. K., \& Stahr, K., 2000. Review of mechanisms and quantification of priming effects. Soil Biol Biochem, 32(11-12), 1485-1498. doi: http://dx.doi.org/10.1016/S00380717(00)00084-5

Kuzyakov, Y.;Subbotina, I.;Chen, H. Q.;Bogomolova, I., \& Xu, X. L., 2009. Black carbon decomposition and incorporation into soil microbial biomass estimated by C-14 labeling. Soil Biol Biochem, 41(2), 210-219. doi: 10.1016/j.soilbio.2008.10.016

Lal, R., 2009. Soils and food sufficiency. A review. Agron. Sustain. Dev, 29, 113-133. doi: 10.1051/agro:2008044

Lawrinenko, M., 2014. Anion exchange capacity of biochar. (Master), Iowa State University, Iowa, USA. (Paper 13685) 
Lehmann, J.;da Silva Jr., J. P.;Steiner, C.;Nehls, T.;Zech, W., \& Glaser, B., 2003. Nutrient availability and leaching in an archaeological anthrosol and a ferralsol of the central amazon basin: fertilizer, manure and charcoal amendments. Plant Soil, 249, 343-357.

Lehmann, J.;Gaunt, J., \& Rondon, M., 2006. Bio-char sequestration in terrestrial ecosystems-a review. Mitig. adapt. strategies glob. chang., 11(2), 395-419.

Lehmann, J., \& Joseph, S., 2009. Biochar for Environmental Management: an introduction. In J. Lehmann \& S. Joseph (Eds.), Biochar for Environmental Management: Science and Technology (pp. 1-12). London: Earthscan.

Lentz, R. D., \& Ippolito, J. A., 2011. Biochar and Manure Affect Calcareous Soil and Corn Silage Nutrient Concentrations and Uptake. J. Environ. Qual., 41, 1033-1043.

Lin, Y.;Munroe, P.;Joseph, S.;Ziolkowski, A.;van Zwieten, L.;Kimber, S., \& Rust, J., 2013. Chemical and structural analysis of enhanced biochars: Thermally treated mixtures of biochar, chicken litter, clay and minerals. Chemosphere, 91(1), 35-40. doi: http://dx.doi.org/10.1016/j.chemosphere.2012.11.063

Liu, B.;Mørkved, P. T.;Frostegård, Å., \& Bakken, L. R., 2010a. Denitrification gene pools, transcription and kinetics of $\mathrm{NO}, \mathrm{N}_{2} \mathrm{O}$ and $\mathrm{N}_{2}$ production as affected by soil $\mathrm{pH}$. FEMS Microbiol Ecol, 72(3), 407-417. doi: 10.1111/j.1574-6941.2010.00856.x

Liu, X. Y.;Zhang, A. F.;Ji, C. Y.;Joseph, S.;Bian, R. J.;Li, L. Q.;Pan, G. X., \& Paz-Ferreiro, J., 2013. Biochar's effect on crop productivity and the dependence on experimental conditions-a metaanalysis of literature data. Plant Soil, 373(1-2), 583-594. doi: 10.1007/s11104-013-1806-x

Liu, Z.;Zhang, F.-S., \& Wu, J., 2010b. Characterization and application of chars produced from pinewood pyrolysis and hydrothermal treatment. Fuel, 89(2), 510-514. doi: http://dx.doi.org/10.1016/j.fuel.2009.08.042

Lua, A. C.;Yang, T., \& Guo, J., 2004. Effects of pyrolysis conditions on the properties of activated carbons prepared from pistachio-nut shells. J. Anal. Appl. Pyrolysis, 72(2), 279-287. doi: http://dx.doi.org/10.1016/j.jaap.2004.08.001 
Luo, Y.;Durenkamp, M.;De Nobili, M.;Lin, Q., \& Brookes, P. C., 2011. Short term soil priming effects and the mineralisation of biochar following its incorporation to soils of different $\mathrm{pH}$. Soil Biol Biochem, 43(11), 2304-2314. doi: 10.1016/j.soilbio.2011.07.020

Lynch, J., 1995. Root Architecture and Plant Productivity. Plan Physiol, 109(1), 7-13.

Malghani, S.;Gleixner, G., \& Trumbore, S. E., 2013. Chars produced by slow pyrolysis and hydrothermal carbonization vary in carbon sequestration potential and greenhouse gases emissions. Soil Biol Biochem, 62, 137-146. doi: http://dx.doi.org/10.1016/j.soilbio.2013.03.013

McLaughlin, H.;Anderson, P. S.;Shields, F. E., \& Reed, T. B. 2009. All Biochars are not Created Equal and How to Tell them Apart. Paper presented at the North American Biochar, Boulder, $\mathrm{CO}$.

Mikkelsen, R., \& Hartz, T. K., 2008. Nitrogen sources for organic crop production. Better Crop, 92(4), 16-19.

Moher, D.;Liberati, A.;Tetzlaff, J., \& Altman, D. G., 2009. Preferred reporting items for systematic reviews and meta-analyses: the PRISMA statement. Ann Intern Med, 151(4), 264-269.

Montes-Morán, M. A.;Suárez, D.;Menéndez, J. A., \& Fuente, E., 2004. On the nature of basic sites on carbon surfaces: an overview. Carbon, 42(7), 1219-1225. doi: http://dx.doi.org/10.1016/j.carbon.2004.01.023

Mørkved, P. T.;Dörsch, P., \& Bakken, L. R., 2007. The $\mathrm{N}_{2} \mathrm{O}$ product ratio of nitrification and its dependence on long-term changes in soil pH. Soil Biol Biochem, 39(8), 2048-2057.

Mukherjee, A.;Zimmerman, A. R., \& Harris, W., 2011. Surface chemistry variations among a series of laboratory-produced biochars. Geoderma, 163, 247-255.

Mukherjee, A., \& Lal, R., 2013. Biochar Impacts on Soil Physical Properties and Greenhouse Gas Emissions. Agronomy, 3, 313-339. 
Naisse, C.;Girardin, C.;Davasse, B.;Chabbi, A., \& Rumpel, C., 2015. Effect of biochar addition on C mineralisation and soil organic matter priming in two subsoil horizons. J Soils Sediments, 15(4), 825-832.

Nelissen, V.;Ruysschaert, G.;Manka’Abusi, D.;D’Hose, T.;De Beuf, K.;Al-Barri, B.;Cornelis, W., \& Boeckx, P., 2015. Impact of a woody biochar on properties of a sandy loam soil and spring barley during a two-year field experiment. Eur J Agron, 62, 65-78. doi: http://dx.doi.org/10.1016/j.eja.2014.09.006

Nguyen, D. B.;Rose, M. T.;Rose, T. J.;Morris, S. G., \& van Zwieten, L., 2016. Impact of glyphosate on soil microbial biomass and respiration: A meta-analysis. Soil Biol Biochem, 92, 50-57. doi: http://dx.doi.org/10.1016/j.soilbio.2015.09.014

Nocentini, C.;Guenet, B.;Mattia, E. D.;Certini, G.;Bardoux, G., \& Rumpel, C., 2010. Charcoal mineralisation potential of microbial inocula from burned and unburned forest soil with and without substrate addition. Soil Biol Biochem, 42, 1472-1478.

Novak, J. M.;Busscher, W. J.;Watts, D. W.;Laird, D. A.;Ahmedna, M. A., \& Niandou, M. A. S., 2010. Short-term $\mathrm{CO}_{2}$ mineralization after additions of biochar and switchgrass to a Typic Kandiudult. Geoderma, 154(3-4), 281-288. doi:

http://dx.doi.org/10.1016/j.geoderma.2009.10.014

Overrein, L., 1969. Lysimeter studies on tracer nitrogen in forest soil: 2. Comparative losses of nitrogen through leaching and volatilization after the addition of urea-, ammonium-and nitrate-n15. Soil Sci, 107(3), 149-159.

Painter, T. J., 1998. Carbohydrate polymers in food preservation: an integrated view of the Maillard reaction with special reference to discoveries of preserved foods in Sphagnum-dominated peat bogs. Carbohydr Polym, 36(4), 335-347. doi: http://dx.doi.org/10.1016/S01448617(97)00258-0

Pignatello, J. J.;Kwon, S., \& Lu, Y., 2006. Effect of Natural Organic Substances on the Surface and Adsorptive Properties of Environmental Black Carbon (Char): Attenuation of Surface 
Activity by Humic and Fulvic Acids. Environ. Sci. Technol., 40(24), 7757-7763. doi: $10.1021 / \mathrm{es} 061307 \mathrm{~m}$

Prommer, J.;Wanek, W.;Hofhansl, F.;Trojan, D.;Offre, P.;Urich, T.;Schleper, C.;Sassmann, S.;Kitzler, B.;Soja, G., \& Nowotny, R. C. H., 2014. Biochar Decelerates Soil Organic Nitrogen Cycling but Stimulates Soil Nitrification in a Temperate Arable Field Trial. PLoS One, 9(1), 1-16.

Qayyum, M. F.;Steffens, D.;Reisenauer, H. P., \& Schubert, S., 2012. Kinetics of carbon mineralization of biochars compared with wheat straw in three soils. J Environ Qual, 41(4), 1210-1220. doi: $10.2134 /$ jeq2011.0058

Quilliam, R. S.;DeLuca, T. H., \& Jones, D. L., 2013. Biochar application reduces nodulation but increases nitrogenase activity in clover. Plant Soil, 366, 83-92.

Reverchon, F.;Flicker, R. C.;Yang, H.;Yan, G.;Xu, Z.;Chen, C.;Bai, S. H., \& Zhang, D., 2014. Changes in $\delta^{15} \mathrm{~N}$ in a soil-plant system under different biochar feedstocks and application rates. Biol. Fertil. Soils, 50, 275-283.

Ridgeway, G., 2013. Package'GBM': Generalized Boosted Regression Models: R Project.

Robertson, S. J.;Rutherford, P. M.;Gutiérrez, J. C. L., \& Massicotte, H. B., 2012. Biochar enhances seedling growth and alters root symbioses and properties of sub-boreal forest soils. Can J Soil Sci, 92(2), 329-340. doi: 10.4141/cjss2011-066

Rondon, M. A.;Lehmann, J.;Ramírez, J., \& Hurtado, M., 2007. Biological nitrogen fixation by common beans (Phaseolus vulgaris L.) increases with bio-char additions. Biol Fertil Soils, 43, 699-708.

Rosa, J. M. d. 1., \& Knicker, H., 2011. Bioavailability of N released from N-rich pyrogenic organic matter, An incubation study. Soil Biol Biochem, 43, 2368-2373.

Rose, M. T.;Patti, A. F.;Little, K. R.;Brown, A. L.;Jackson, W. R., \& Cavagnaro, T. R., 2014. A meta-analysis and review of plant-growth response to humic substances: practical 
implications for agriculture. In D. L. Sparks (Ed.), Advances in Agronomy (Vol. 124, pp. 37): Elsevier.

Rosenberg, M. S.;Adams, D. C., \& Gurevitch, J., 2000. MetaWin (Version 2). Retrieved from http://www.metawinsoft.com/

Rosenthal, R., \& Rosnow, R. L., 1984. Essentials of behavioral research: methods and data analysis: McGraw-Hill Higher Education.

Rosillo-Calle, F.;de Groot, P.;Hemstock, S. L., \& Woods, J., 2015. The Biomass Assessment Handbook: Energy for a Sustainable Environment: Taylor \& Francis.

Rosnitschek-Schimmel, I., 1982. Effect of Ammonium and Nitrate Supply on Dry Matter Production and Nitrogen Distribution in Urtica dioica. Z Pflanzenphysiol, 108(4), 329-341. doi: http://dx.doi.org/10.1016/S0044-328X(82)80179-7

Rothstein, H. R.;Sutton, A. J., \& Borenstein, M., 2006. Publication Bias in Meta-Analysis Publication Bias in Meta-Analysis (pp. 1-7): John Wiley \& Sons, Ltd.

Saarnio, S.;Heimonen, K., \& Kettunen, R., 2013. Biochar addition indirectly affects $\mathrm{N}_{2} \mathrm{O}$ emissions via soil moisture and plant N uptake. Soil Biol Biochem, 58, 99-106.

Sahrawat, K. L., 2008. Factors affecting nitrification in soils. Comm Soil Sci Plant Anal, 39(9-10), 1436-1446. doi: 10.1080/00103620802004235

Saleh, M. E.;Mahmoud, A. H., \& Rashad, M., 2012. Peanut Biochar as a Stable Adsorbent for Removing NH4-N from Wastewater: A Preliminary Study. Adv. Environ. Biol., 6(7), 21702176.

Saxton, K. E., \& Rawls, W., 2009. Hydraulic Properties Calculator. Pullman, USA: Washington State University. Retrieved from http://hydrolab.arsusda.gov/soilwater/Index.htm

Schimel, J. P., \& Bennett, J., 2004. Nitrogen mineralization: challenges of a changing paradigm. Ecology, 85(3), 591-602. doi: 10.1890/03-8002 
Shen, J.;Tang, H.;Liu, J.;Wang, C.;Li, Y.;Ge, T.;Jones, D. L., \& Wu, J., 2014. Contrasting effects of straw and straw-derived biochar amendments on greenhouse gas emissions within double rice cropping systems. Agric Ecosyst Environ, 188, 264-274.

Simpson, R. F., \& McQuilkin, R. M., 1976. Identification of volatiles from felled pinus radiata and the electroantennograms they elicit from sirex noctilio. Entomol Exp Appl, 19(3), 205-213. doi: $10.1111 / \mathrm{j} .1570-7458.1976 . t b 02599 . x$

Singh, B. P.;Hatton, B. J.;Balwant, S.;Cowie, A. L., \& Kathuria, A., 2010. Influence of biochars on nitrous oxide emission and nitrogen leaching from two contrasting soils. J Environ Qual, 39(4), 1224-1235.

Singh, B. P.;Cowie, A. L., \& Smernik, R. J., 2012. Biochar carbon stability in a clayey soil as a function of feedstock and pyrolysis temperature. Environ Sci Technol, 46(21), 11770-11778.

Singh, B. P., \& Cowie, A. L., 2014. Long-term influence of biochar on native organic carbon mineralisation in a low-carbon clayey soil. Sci Rep., 4, 3687. doi: 10.1038/srep03687 http://www.nature.com/articles/srep03687\#supplementary-information

Smith, J. L.;Collins, H. P., \& Bailey, V. L., 2010. The effect of young biochar on soil respiration. Soil Biol Biochem, 42(12), 2345-2347. doi: http://dx.doi.org/10.1016/j.soilbio.2010.09.013

Song, Y.;Zhang, X.;BinMa;Chang, S. X., \& Gong, J., 2014. Biochar addition affected the dynamics of ammonia oxidizers and nitrification in microcosms of a coastal alkaline soil. Biol. Fertil. Soils, 50, 321-332.

Spokas, K.;Baker, J., \& Reicosky, D., 2010. Ethylene: potential key for biochar amendment impacts. Plant Soil, 333(1-2), 443-452. doi: 10.1007/s11104-010-0359-5

Sullivan, D. M., \& Miller, R. O., 2001. Compost quality attributes, measurements, and variability: CRC Press, Boca Raton, Florida.

Taghizadeh-Toosi, A.;Clough, T.;Sherlock, R., \& Condron, L., 2012a. Biochar adsorbed ammonia is bioavailable. Plant Soil, 350(1-2), 57-69. doi: 10.1007/s11104-011-0870-3 
Taghizadeh-Toosi, A.;Clough, T. J.;Sherlock, R. R., \& Condron, L. M., 2012b. A wood based lowtemperature biochar captures $\mathrm{NH}_{3}-\mathrm{N}$ generated from ruminant urine- $\mathrm{N}$, retaining its bioavailability. Plant Soil, 353, 73-84.

Thies, J. E.;Rillig, M. C., \& Graber, E. R., 2015. Biochar effects on the abundance activity and diversity of the soil biota. In J. Lehmann \& J. Stephen (Eds.), Biochar for Environmental Management: Science, Technology and Implementation (2 ed., pp. 327-389): Routledge.

Ulyett, J.;Sakrabani, R.;Kibblewhite, M., \& Hann, M., 2014. Impact of biochar addition on water retention, nitrification and carbon dioxide evolution from two sandy loam soils. Eur. J. Soil Sci., 65, 96-104.

van Zwieten, L.;Singh, B.;Stephen, J.;Kimber, S.;Cowie, A., \& Chan, K. Y., 2009. Biochar and emissions of non- $\mathrm{CO}_{2}$ greenhouse gases from soil. In J. Lehmann \& J. Stephen (Eds.), Biochar for environmental management: Science and Technology (1 ed., pp. 227-250). London: Earthscan.

van Zwieten, L.;Kimber, S.;Morris, S.;Chan, K. Y.;Downie, A.;Rust, J.;Joseph, S., \& Cowie, A., 2010a. Effects of biochar from slow pyrolysis of papermill waste on agronomic performance and soil fertility. Plant Soil, 327, 235-246.

van Zwieten, L.;Kimber, S.;Morris, S.;Downie, A.;Berger, E.;Rust, J., \& Scheer, C., 2010b. Influence of biochars on flux of $\mathrm{N}_{2} \mathrm{O}$ and $\mathrm{CO}_{2}$ from Ferrosol. Soil Res., 48(7), 555-568. doi: http://dx.doi.org/10.1071/SR10004

van Zwieten, L.;Kimber, S. W. L.;Morris, S. G.;Singh, B. P.;Grace, P. R.;Scheer, C.;Rust, J.;Downie, A. E., \& Cowie, A. L., 2013. Pyrolysing poultry litter reduces $\mathrm{N}_{2} \mathrm{O}$ and $\mathrm{CO}_{2}$ fluxes. Sci Total Environ, 465, 279-287.

Ventura, M.;Sorrenti, G.;Panzacchi, P.;George, E., \& Tonon, G., 2013. Biochar Reduces Short-Term Nitrate Leaching from A Horizon in an Apple Orchard. J Environ Qual, 42(1), 76-82. doi: $10.2134 /$ jeq 2012.0250 
Wang, J.;Pan, X.;Liu, Y.;Zhang, X., \& Xiong, Z., 2012. Effects of biochar amendment in two soils on greenhouse gas emission and crop production. Plant Soil, 360(1), 287-298. doi: DOI $10.1007 / \mathrm{s} 11104-012-1250-3$

Wang, J.;Xiong, Z., \& Kuzyakov, Y., 2016. Biochar stability in soil: meta-analysis of decomposition and priming effects. GCB Bioenergy, 8(3), 512-523. doi: 10.1111/gcbb.12266

Ward, B.;Courtney, K., \& Langenheim, J., 1997. Inhibition of Nitrosomonas europaea by monoterpenes from coastal redwood (Sequoia sempervirens) in whole-cell studies. J Chem Ecol, 23(11), 2583-2598.

Weng, Z. H.;Van Zwieten, L.;Singh, B. P.;Kimber, S.;Morris, S.;Cowie, A., \& Macdonald, L. M., 2015. Plant-biochar interactions drive the negative priming of soil organic carbon in an annual ryegrass field system. Soil Biol Biochem, 90, 111-121.

Whitman, T.;Singh, B. P., \& Zimmerman, A. R., 2015. Priming effect in biochar-amended soils: implication of biochar-soil organic matter interactions for carbon storage. In J. Lehmann \& S. Joseph (Eds.), Biochar for Environmental Management: Science, Technology and Implementation (2 ed., pp. 455-488). New York: Routledge.

Xing, G., \& Zhu, Z., 2000. An assessment of $\mathrm{N}$ loss from agricultural fields to the environment in China. Nutr Cycl Agroecos, 57(1), 67-73.

Xu, C. Y.;Bai, S. H.;Hao, Y.;Rachaputi, R. N.;Wang, H.;Xu, Z., \& Wallace, H., 2015. Effect of biochar amendment on yield and photosynthesis of peanut on two types of soils. Environ. Sci. Pollut. Res., 22(8), 6112-6125. doi: 10.1007/s11356-014-3820-9

Ye, J.;Zhang, R.;Nielsen, S.;Joseph, S. D.;Huang, D., \& Thomas, T., 2016. A combination of biochar-mineral complexes and compost improves soil bacterial processes, soil quality and plant properties. Front Microbiol, 7, 372.

Yuan, J.-H.;Xu, R.-K., \& Zhang, H., 2011. The forms of alkalis in the biochar produced from crop residues at different temperatures. Bioresource Technol, 102(3), 3488-3497. doi: http://dx.doi.org/10.1016/j.biortech.2010.11.018 
Zackrisson, O.;Nilsson, M. C., \& Wardle, D. A., 1996. Key Ecological Function of Charcoal from Wildfire in the Boreal Forest. Oikos, 77(1), 10-19. doi: 10.2307/3545580

Zavalloni, C.;Alberti, G.;Biasiol, S.;Delle Vedove, G.;Fornasier, F.;Liu, J., \& Peressotti, A., 2011. Microbial mineralization of biochar and wheat straw mixture in soil: A short-term study. Appl Soil Ecol, 50, 45-51. doi: 10.1016/j.apsoil.2011.07.012

Zhang, A.;Liu, Y.;Pan, G.;Hussain, Q.;Li, L.;Zheng, J., \& Zhang, X., 2012. Effect of biochar amendment on maize yield and greenhouse gas emissions from a soil organic carbon poor calcareous loamy soil from Central China Plain. Plant Soil, 351, 263-275.

Zhang, W.;Yuan, S.;Hu, N.;Lou, Y., \& Wang, S., 2015. Predicting soil fauna effect on plant litter decomposition by using boosted regression trees. Soil Biol Biochem, 82, 81-86. doi: http://dx.doi.org/10.1016/j.soilbio.2014.12.016

Zhang, X.;Liu, W.;Schloter, M.;Zhang, G.;Chen, Q.;Huang, J.;Li, L.;Elser, J. J., \& Han, X., 2013. Response of the Abundance of Key Soil Microbial Nitrogen-Cycling Genes to Multi-Factorial Global Changes. PLoS One. 8(10): e76500. doi:10.1371/journal.pone.0076500

Zhao, R.;Coles, N., \& Wu, J., 2015. Carbon mineralization following additions of fresh and aged biochar to an infertile soil. Catena, 125, 183-189. doi: http://dx.doi.org/10.1016/j.catena.2014.10.026

Zhao, X.;ShenqiangWang, \& Xing, G., 2014. Nitrification, acidification, and nitrogen leaching from subtropical cropland soils as affected by rice straw-based biochar, laboratory incubation and column leaching studies. J Soils Sediments, 14, 471-482.

Zheng, J.;Stewart, C. E., \& Cotrufo, M. F., 2012. Biochar and Nitrogen Fertilizer Alters Soil Nitrogen Dynamics and Greenhouse Gas Fluxes from Two Temperate Soils. J Environ Qual, $41,1361-1370$.

Zheng, W.;Sharma, B. K., \& Rajagopalan, N., 2010. Using Biochar as a Soil Amendment for Sustainable Agriculture. Illinois Department of Agriculture Sustainable Agriculture Grant's Research Report Series. 
Zimmerman, A. R.;Gao, B., \& Ahn, M.-Y., 2011. Positive and negative carbon mineralization priming effects among a variety of biochar-amended soils. Soil Biol Biochem, 43, 1169-1179. 
Figure 1: Summarised effects of biochar properties on mechanisms affecting soil mineral N. The mark $(+)$ or $(-)$ present the increased or decreased $\mathrm{N}$ transformation processes.

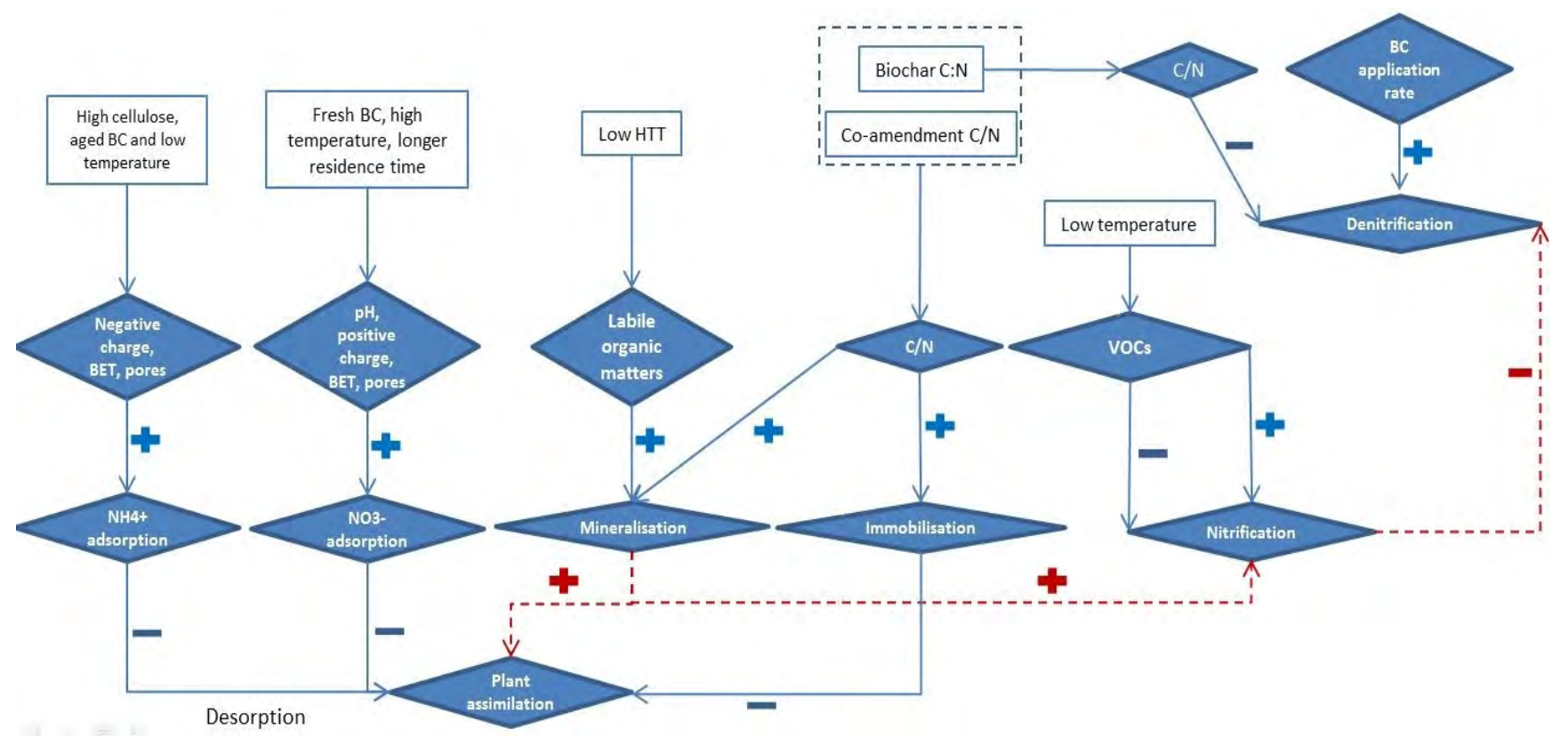


Figure 2: Grand mean of all cases for $\mathrm{NH}_{4}{ }^{+}-\mathrm{N}$ and $\mathrm{NO}_{3}{ }^{-}-\mathrm{N}$ when biochar was applied regardless of experimental conditions

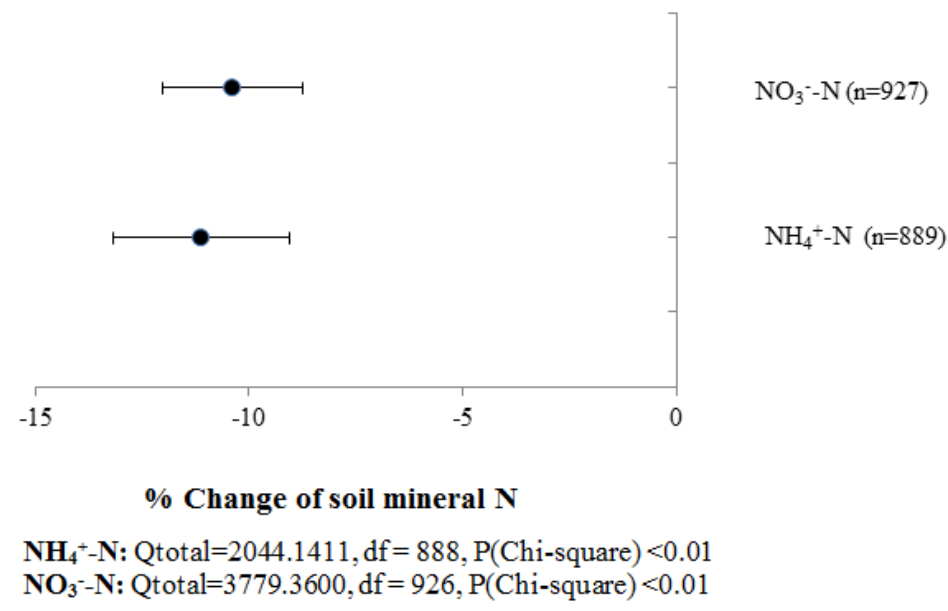


Figure 3: Influence of different feedstock used to produce biochar on $\mathrm{NH}_{4}{ }^{-} \mathrm{N}$ and $\mathrm{NO}_{3}{ }^{-} \mathrm{N}$ availability in soil. Symbols represent mean effect sizes (percentage of change in $\mathrm{NH}_{4}{ }^{+}-\mathrm{N}$ (a) and $\mathrm{NO}_{3}{ }^{-}-\mathrm{N}$ content (b)) with $95 \%$ confidence intervals. The numbers shown on the right correspond to observations in each class upon which the statistical analysis is based (n). The dotted line indicates the mean effect size for all feedstocks when biochar is applied to soil.

a
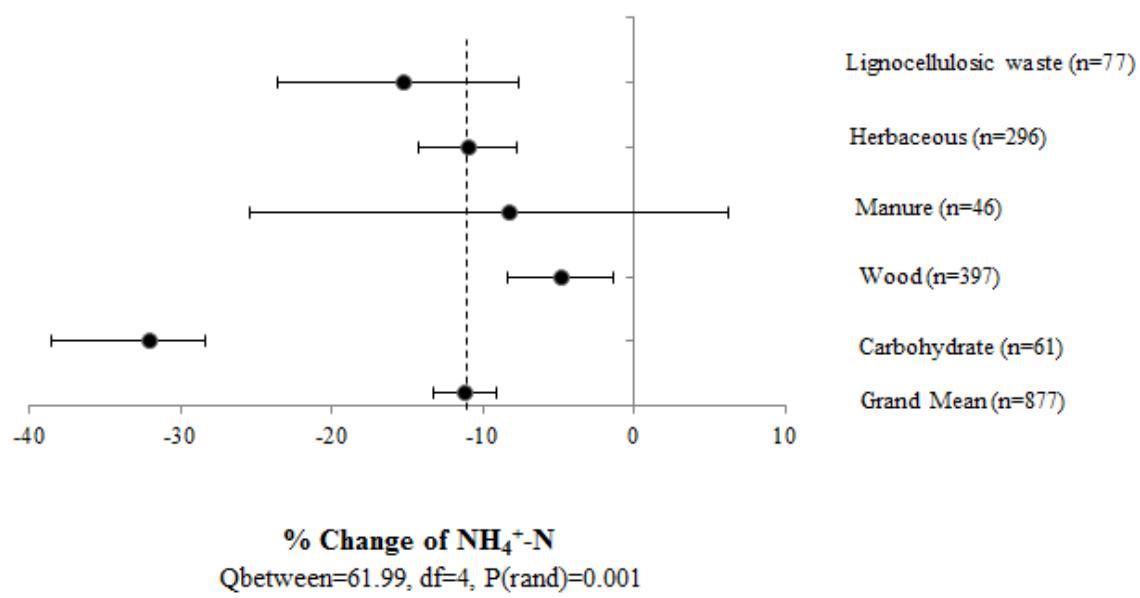

b

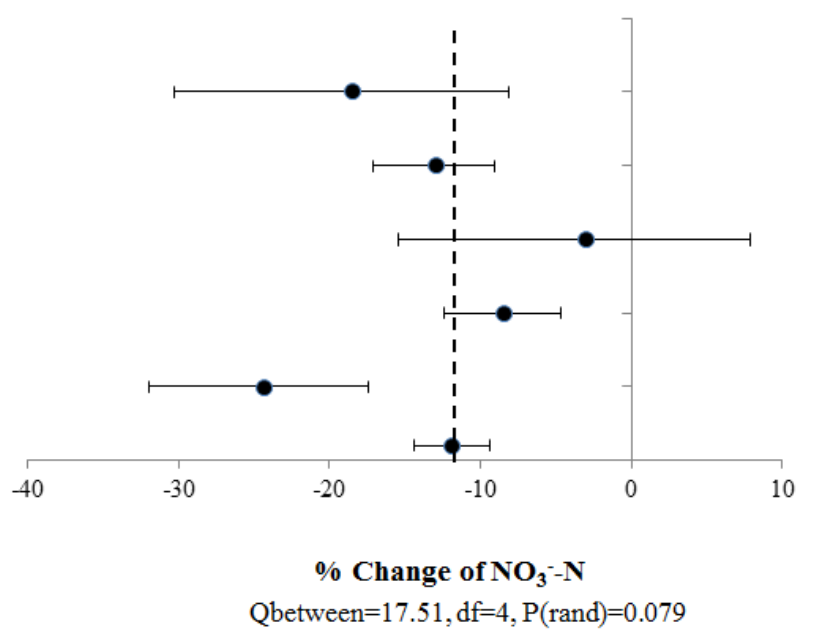

Lignocellulosic waste $(\mathrm{n}=67)$
Herbaceous ( $\mathrm{n}=303)$
Manure $(\mathrm{n}=57)$
Wood ( $\mathrm{n}=417)$
Carbohydrate $(\mathrm{n}=63)$
Grand Mean $(\mathrm{n}=907)$

Qbetween $=17.51, \mathrm{df}=4, \mathrm{P}(\mathrm{rand})=0.079$ 
Figure 4: Influence of pyrolysis temperature used to produce biochar on $\mathrm{NH}_{4}{ }^{+}-\mathrm{N}$ and $\mathrm{NO}_{3}{ }^{-} \mathrm{N}$ availability in soil. Symbols represent mean effect sizes (percentage of change in $\mathrm{NH}_{4}{ }^{+}-\mathrm{N}$ (a) and $\mathrm{NO}_{3}{ }^{-}-\mathrm{N}$ content (b)) with $95 \%$ confidence intervals. The numbers shown on the right correspond to observations in each class upon which the statistical analysis is based (n). The dotted line indicates the mean effect size for all ranges of temperature when biochar is applied to soil.

A

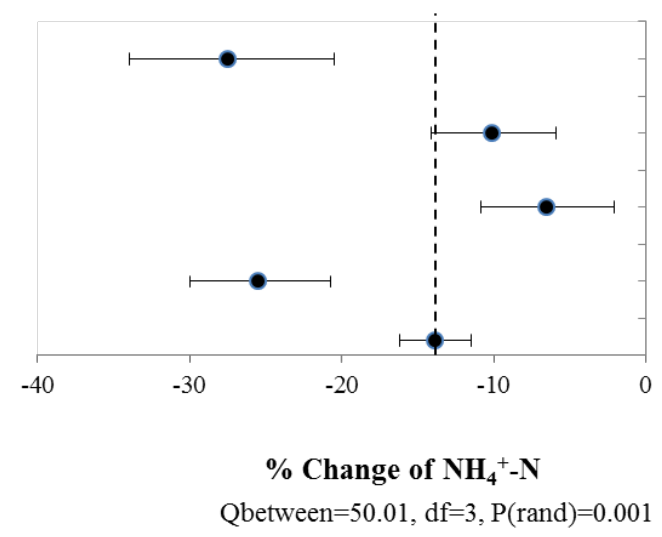

$>600(n=109)$

$501-600(\mathrm{n}=345)$

$401-501(n=230)$

$<401(\mathrm{n}=148)$

Grand Mean $(n=832)$

b

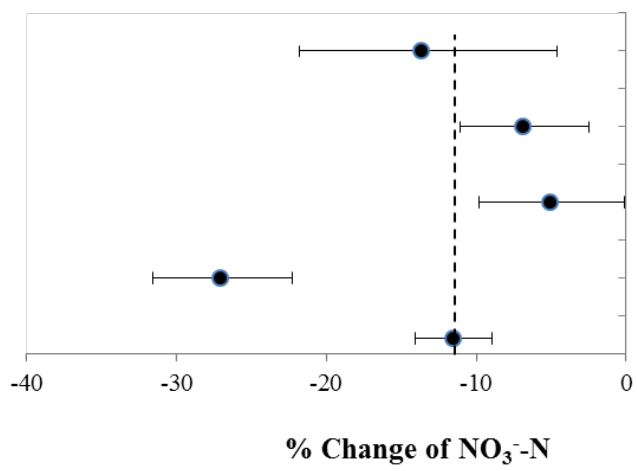

$>600(\mathrm{n}=94)$

$501-600(n=354)$

401-501 ( $=244)$

$<401(\mathrm{n}=170)$

Grand Mean $(\mathrm{n}=862)$

Qbetween $=48.33, \mathrm{df}=3, \mathrm{P}($ rand $)=0.001$ 
Figure 5: Influence of pyrolysis type used to produce biochar on $\mathrm{NH}_{4}{ }^{+}-\mathrm{N}$ and $\mathrm{NO}_{3}{ }^{-} \mathrm{N}$ availability in soil. Symbols represent mean effect sizes (percentage of change in $\mathrm{NH}_{4}{ }^{+}-\mathrm{N}$ (a) and $\mathrm{NO}_{3}{ }^{-}-\mathrm{N}_{\text {content }}$ (b)) with $95 \%$ confidence intervals. The numbers shown on the right correspond to observations in each class upon which the statistical analysis is based (n). The dotted line indicates the mean effect size for all pyrolysis types when biochar is applied to soil.

a

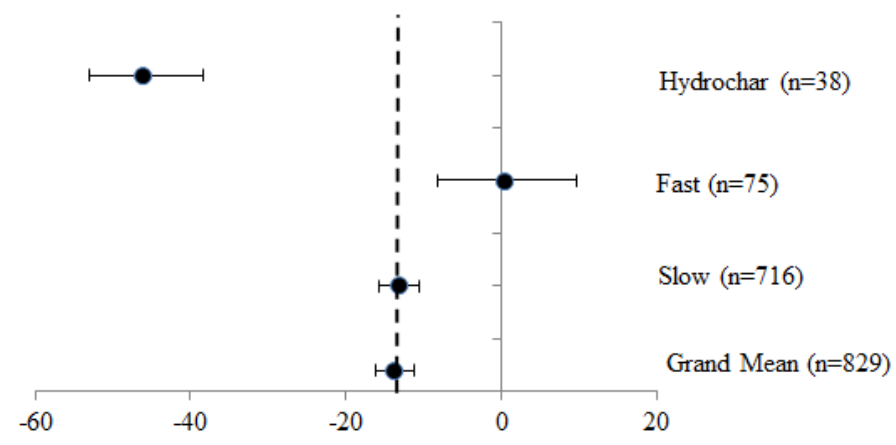

$\%$ Change of $\mathrm{NH}_{4}^{+}-\mathrm{N}$

Qbetween $=60.51, \mathrm{df}=2, \mathrm{P}($ rand $)=0.001$

b

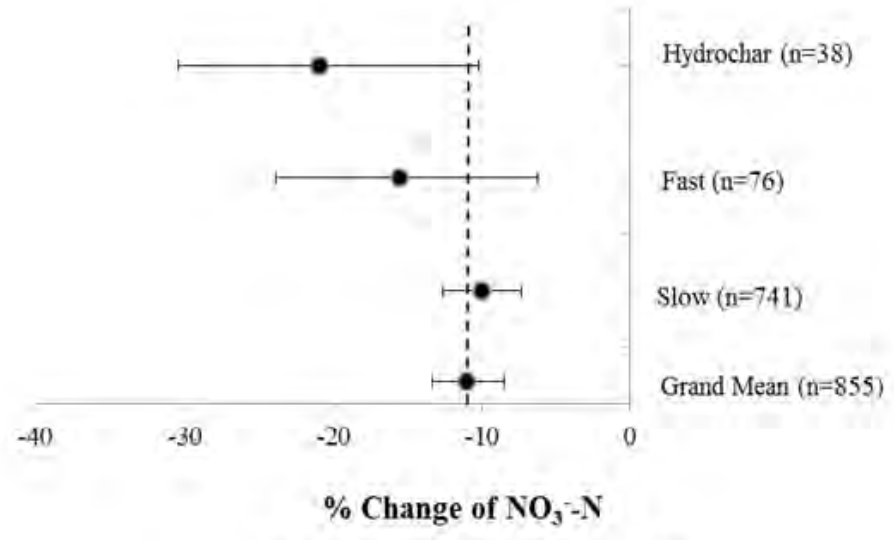

Qbetween $=5.12, \mathrm{df}=2, \mathrm{P}(\mathrm{rand})=0.332$ 
Figure 6: Influence of application rate (\% weight) on changes on $\mathrm{NH}_{4}{ }^{+}-\mathrm{N}^{-}$and $\mathrm{NO}_{3}{ }^{-}-\mathrm{N}$ availability in soil. Symbols represent mean effect sizes (percentage of change in $\mathrm{NH}_{4}{ }^{+}-\mathrm{N}$ (a) and $\mathrm{NO}_{3}{ }^{-}-\mathrm{N}$ content (b)) with $95 \%$ confidence intervals. The numbers shown on the right correspond to observations in each class upon which the statistical analysis is based (n). The dotted line indicates the mean effect size for all application rates when biochar is applied to soil.

a

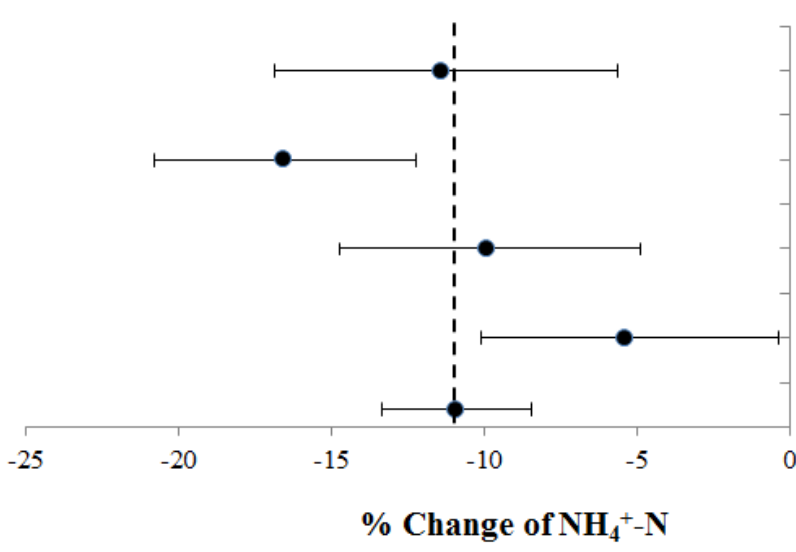

$(5-10)(n=152)$

$(2-5)(n=224)$

$(1-2)(n=189)$

$(<1)(n=315)$

Grand Mean $(\mathrm{n}=880)$

Qbetween $=11.95, \mathrm{df}=3, \mathrm{P}(\mathrm{rand})=0.118$

b

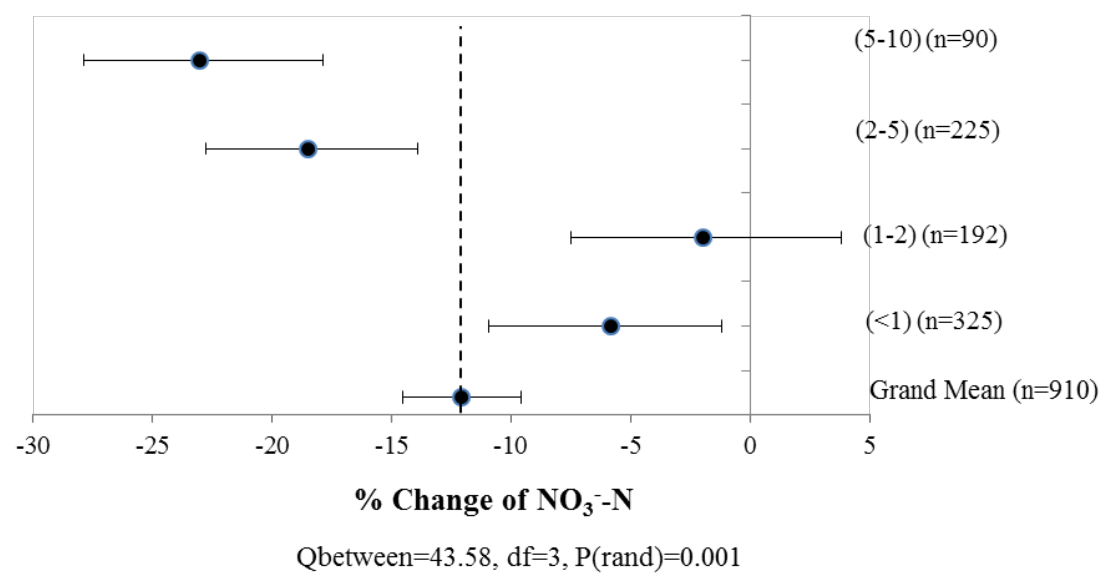


Figure 7: Influence of time of biochar in soil on $\mathrm{NH}_{4}{ }^{+}-\mathrm{N}$ and $\mathrm{NO}_{3}{ }^{-}-\mathrm{N}$ availability in soil. Symbols represent mean effect sizes (percentage of change in $\mathrm{NH}_{4}{ }^{+}-\mathrm{N}$ (a) and $\mathrm{NO}_{3}{ }^{-}-\mathrm{N}$ content (b)) with $95 \%$ confidence intervals. The numbers shown on the right correspond to observations in each class upon which the statistical analysis is based (n). The dotted line indicates the mean effect size for all time ranges when biochar is applied to soil.

a

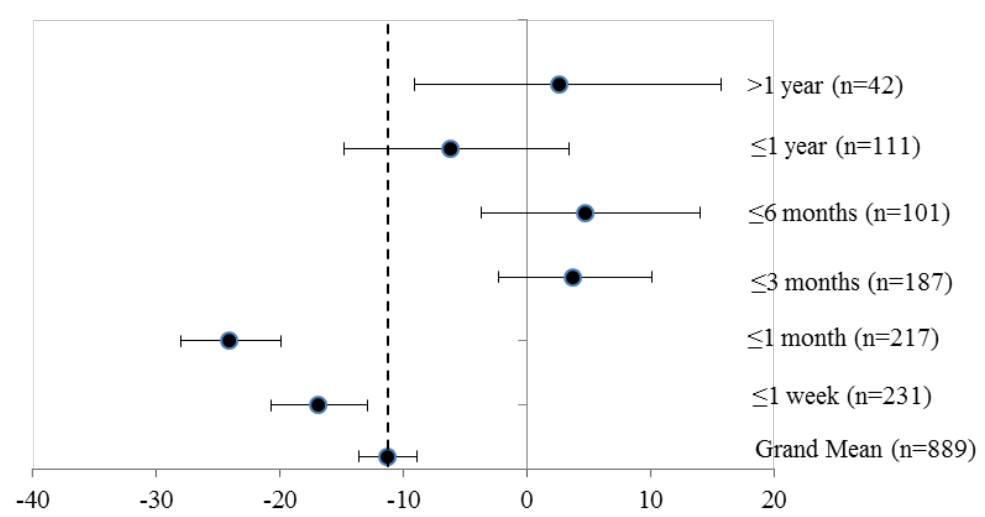

$\%$ Change of $\mathrm{NH}_{4}{ }^{+}-\mathrm{N}$

Qbetween $=89.65, \mathrm{df}=5, \mathrm{P}(\mathrm{rand})=0.001$

b

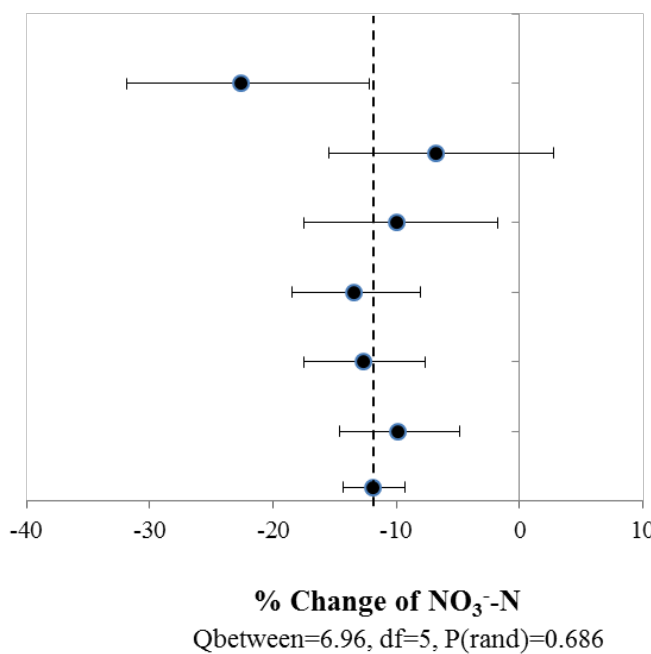

$>1$ year $(\mathrm{n}=42)$

$\leq 1$ year $(\mathrm{n}=115)$

$\leq 6$ months $(\mathrm{n}=109)$

$\leq 3$ months $(\mathrm{n}=201)$

$\leq 1$ month $(\mathrm{n}=217)$

$\leq 1$ week $(\mathrm{n}=235)$

Grand Mean (n=917)

Qbetween $=6.96, \mathrm{df}=5, \mathrm{P}($ rand $)=0.686$ 
Figure 8: Influence of $\mathrm{N}$-fertiliser type on changes on $\mathrm{NH}_{4}{ }^{+}-\mathrm{N}$ and $\mathrm{NO}_{3}{ }^{-} \mathrm{N}$ availability in soil. Symbols represent mean effect sizes (percentage of change in $\mathrm{NH}_{4}{ }^{+}-\mathrm{N}$ (a) and $\mathrm{NO}_{3}{ }^{-}-\mathrm{N}$ content (b)) with $95 \%$ confidence intervals. The numbers shown on the right correspond to observations in each class upon which the statistical analysis is based (n). The dotted line indicates the mean effect size for all fertilisation types when biochar is co-applied to soil.

a

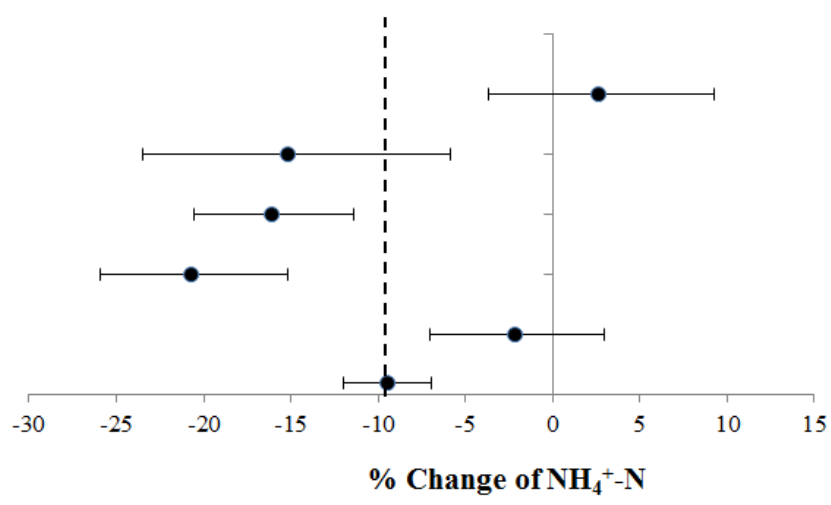

Organic $(\mathrm{n}=226)$

Urea $(\mathrm{n}=58)$

$\mathrm{NH}_{4} \mathrm{NO}_{3}(\mathrm{n}=179)$

$\mathrm{NH}_{4}$-based ( $\left.\mathrm{n}=104\right)$

Unfertilised $(n=274)$

Grand Mean $(\mathrm{n}=848)$

Qbetween $=48.59, \mathrm{df}=4, \mathrm{P}(\mathrm{rand})=0.001$

b

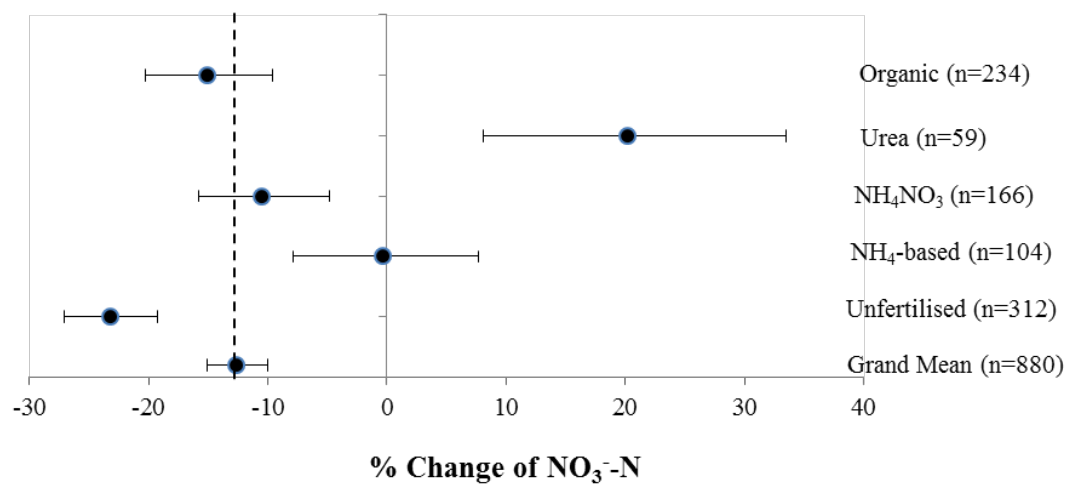

Qbetween $=74.41, \mathrm{df}=4, \mathrm{P}($ rand $)=0.001$ 
Figure 9: Influence of soil texture on $\mathrm{NH}_{4}{ }^{+}-\mathrm{N}$ and $\mathrm{NO}_{3}{ }^{-} \mathrm{N}$ availability in soil. Symbols represent mean effect sizes (percentage of change in $\mathrm{NH}_{4}{ }^{+}-\mathrm{N}$ (a) and $\mathrm{NO}_{3}{ }^{-}-\mathrm{N}$ content (b)) with $95 \%$ confidence intervals. The numbers shown on the right correspond to observations in each class upon which the statistical analysis is based (n). The dotted line indicates the mean effect size for all soil texture types when biochar is co-applied to soil.

a

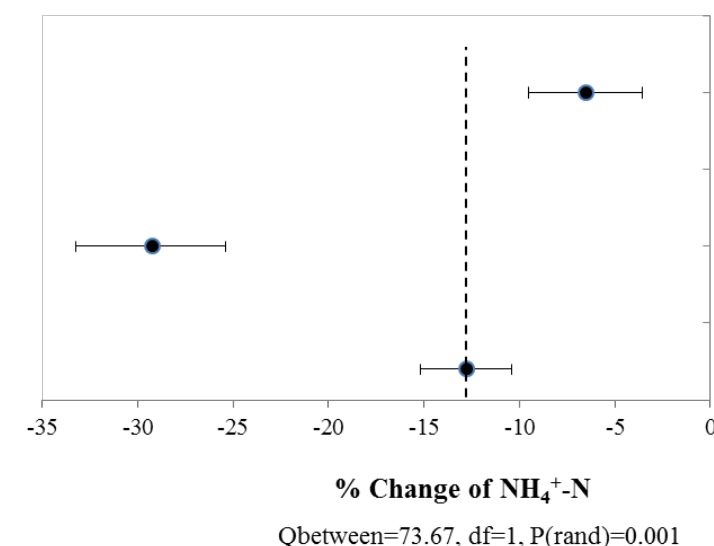

Medium (n=655)

Coarse $(\mathrm{n}=161)$

Grand Mean (n=816)

b

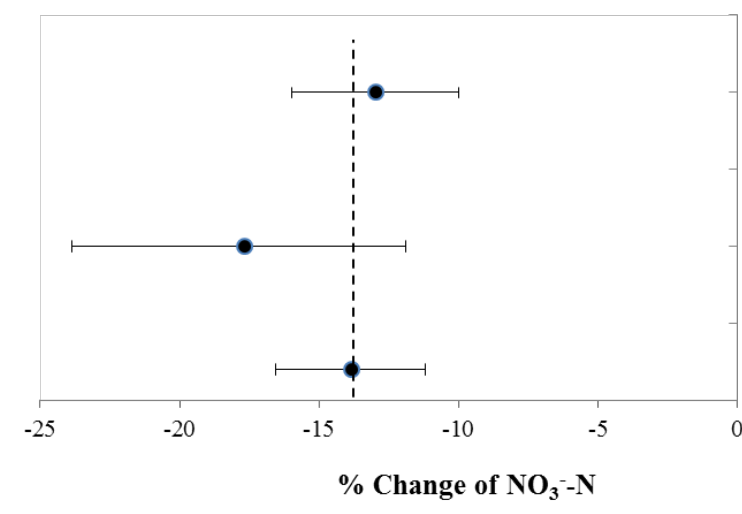

Medium (n=699)

Coarse $(\mathrm{n}=147)$

Grand mean $(\mathrm{n}=846)$

Qbetween $=1.87, \mathrm{df}=1, \mathrm{P}(\mathrm{rand})=0.346$ ) 
Figure 10: Influence of soil $\mathrm{pH}$ on $\mathrm{NH}_{4}{ }^{+}-\mathrm{N}$ and $\mathrm{NO}_{3}{ }^{-}-\mathrm{N}$ availability in soil. Symbols represent mean effect sizes (percentage of change in $\mathrm{NH}_{4}{ }^{+}-\mathrm{N}$ (a) and $\mathrm{NO}_{3}{ }^{-}-\mathrm{N}$ content (b)) with $95 \%$ confidence intervals. The numbers shown on the right correspond to observations in each class upon which the statistical analysis is based (n). The dotted line indicates the mean effect size for all $\mathrm{pH}$ ranges when biochar is co-applied to soil.

A

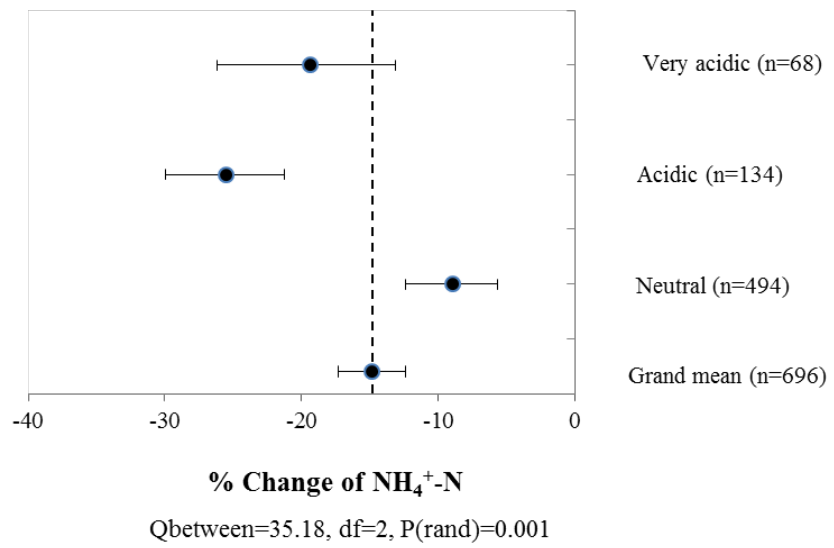

B

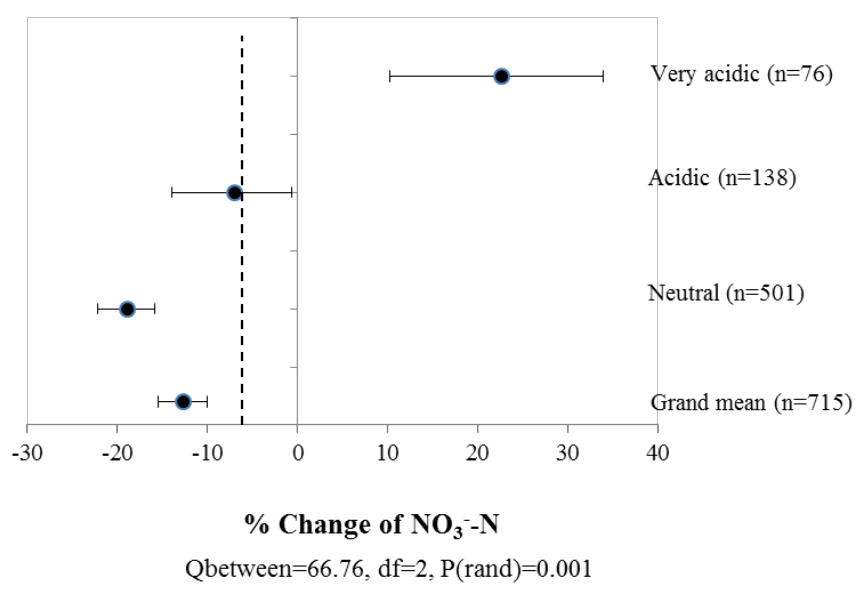


Figure 11: Influence of crop type on $\mathrm{NH}_{4}{ }^{+}-\mathrm{N}$ and $\mathrm{NO}_{3}{ }^{-} \mathrm{N}$ availability in soil. Symbols represent mean effect sizes (percentage of change in $\mathrm{NH}_{4}{ }^{+}-\mathrm{N}$ (a) and $\mathrm{NO}_{3}{ }^{-}-\mathrm{N}$ content (b)) with $95 \%$ confidence intervals. The numbers shown on the right correspond to observations in each class upon which the statistical analysis is based (n). The dotted line indicates the mean effect size for all $\mathrm{pH}$ ranges when biochar is co-applied to soil.

a

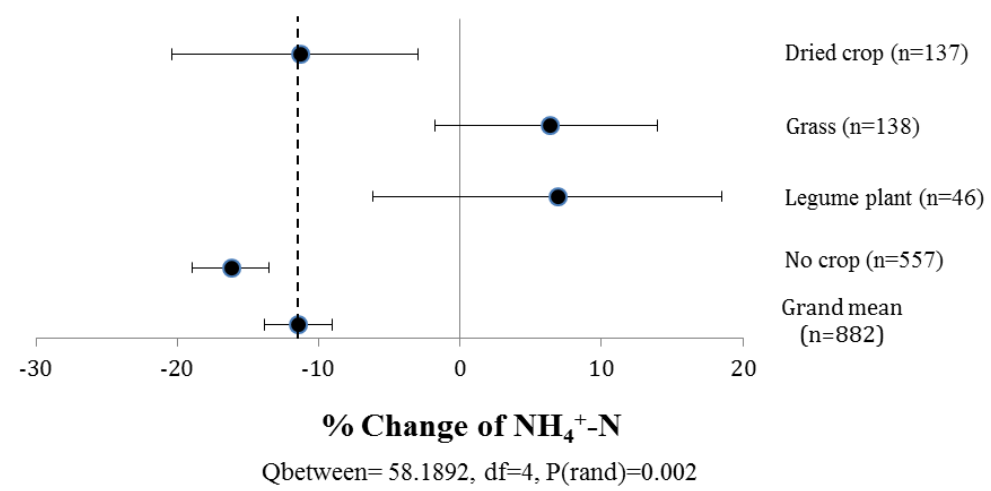

b

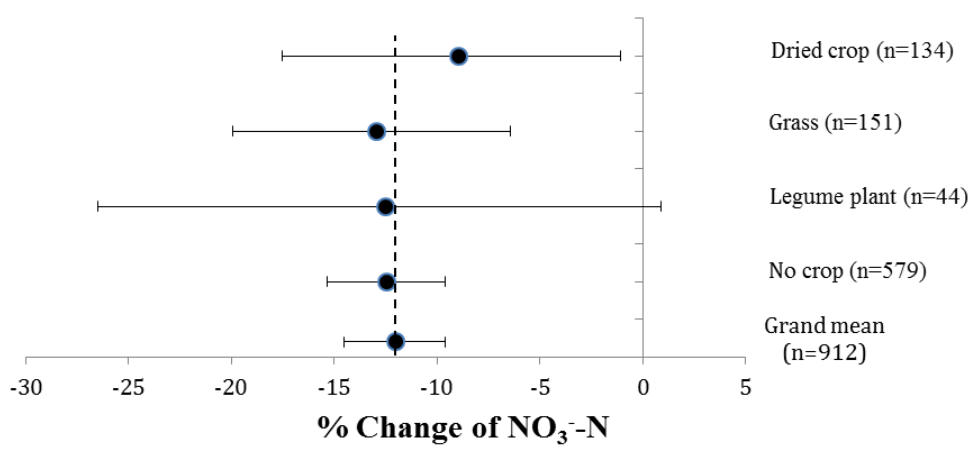

Qbetween $=3.6424, \mathrm{df}=4, \mathrm{P}(\mathrm{rand})=0.738$ 
Figure 12: Partial dependence plots (a, c, e) and fitted values (b, d, f) showing the effects of biochar BET surface area, CEC, and VOCs on soil $\mathrm{NH}_{4}{ }^{+}-\mathrm{N}$, and partial dependence plots $(\mathrm{g}, \mathrm{i})$ and fitted values (h, k) showing the effects of biochar BET surface area, and VOCs on soil $\mathrm{NO}_{3}{ }^{-} \mathrm{N}$. The fitted function shows the relationship between effect sizes and an explanatory variable while all other explanatory variables are kept constant at their mean level. The dashed lines showed no effect level.

Fitted functions

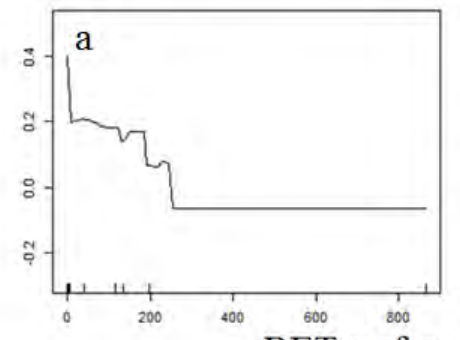

BET surface area $\left(\mathrm{m}^{2} / \mathrm{g}\right)$
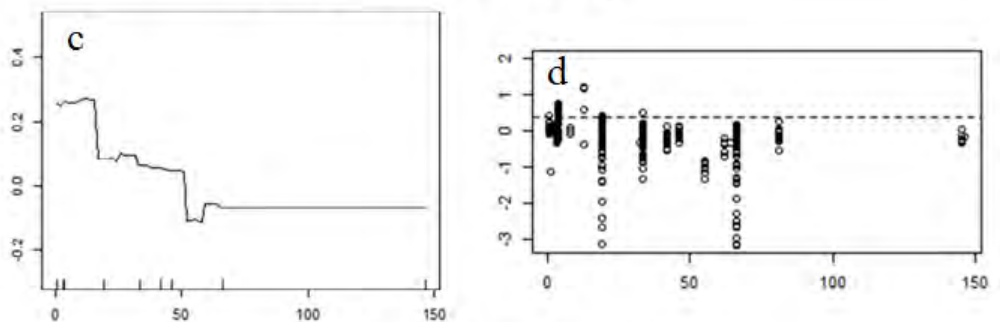

$\mathrm{CEC}(\mathrm{cmol} / \mathrm{kg})$
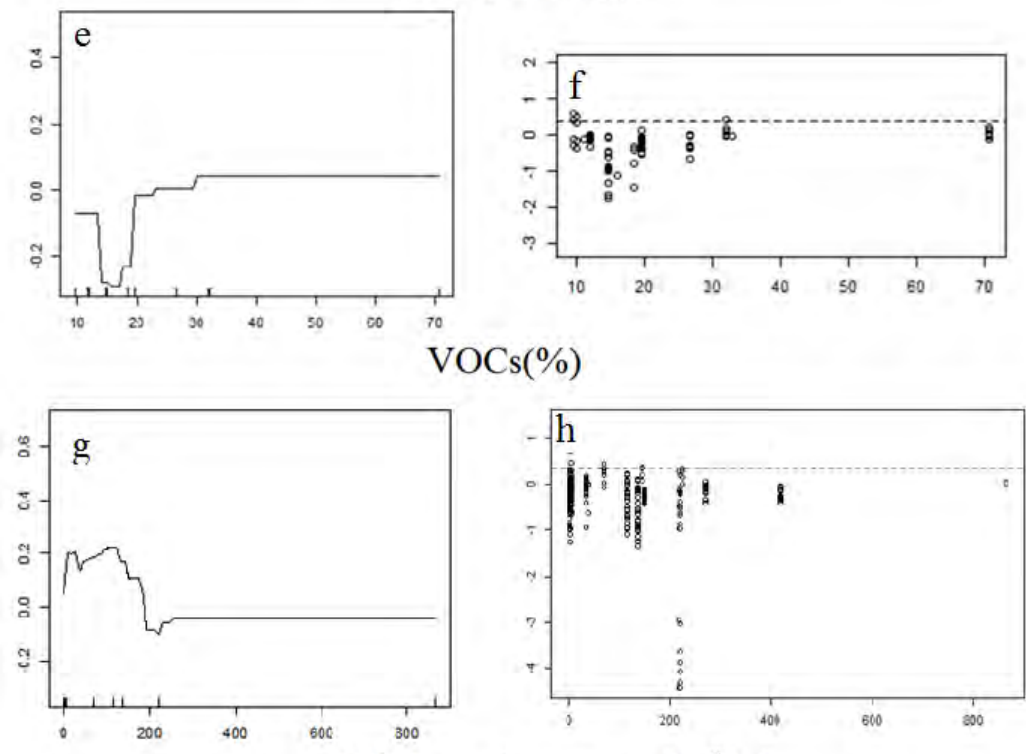

BET surface area $\left(\mathrm{m}^{2} / \mathrm{g}\right)$
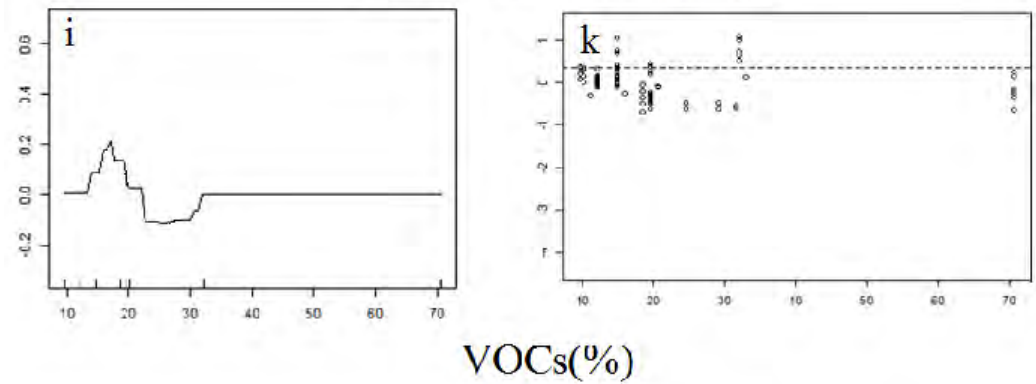


\begin{tabular}{|c|c|c|c|c|c|c|c|}
\hline \multirow[t]{2}{*}{ Factor } & \multirow[t]{2}{*}{$\mathrm{N}$ form } & \multicolumn{2}{|c|}{ Funnel plot statistics } & \multirow{2}{*}{$\begin{array}{l}\text { Fail-safe } \\
\text { numbers }\end{array}$} & \multirow[t]{2}{*}{$5 n+1$} & \multirow{2}{*}{$\begin{array}{l}\text { Existence } \\
\text { of bias }\end{array}$} & \multirow{2}{*}{$\begin{array}{l}\text { Does bias } \\
\text { affect the } \\
\text { trend? }\end{array}$} \\
\hline & & $\begin{array}{l}\text { Kendall's } \\
\text { Tau }\end{array}$ & $\begin{array}{l}\text { Spearman Rank- } \\
\text { Order Correlation }\end{array}$ & & & & \\
\hline \multirow{2}{*}{$\begin{array}{l}\text { Pyrolysis } \\
\text { temperature }\end{array}$} & $\mathrm{NH}_{4}^{+}-\mathrm{N}$ & 0.02615 & 0.05423 & 43446.2 & 4161 & Yes & No \\
\hline & $\mathrm{NO}_{3}{ }^{-}-\mathrm{N}$ & 0.95578 & 0.87989 & & & No & No \\
\hline \multirow[t]{2}{*}{ Pyrolysis type } & $\mathrm{NH}_{4}^{+}-\mathrm{N}$ & 0.02375 & 0.05102 & 41113.8 & 4146 & Yes & No \\
\hline & $\mathrm{NO}_{3}^{-}-\mathrm{N}$ & 0.92125 & 0.82982 & & & No & No \\
\hline \multirow[t]{2}{*}{ Feedstock } & $\mathrm{NH}_{4}^{+}-\mathrm{N}$ & 0.00023 & 0.00143 & 31746.3 & 4386 & Yes & No \\
\hline & $\mathrm{NO}_{3}^{-}-\mathrm{N}$ & 0.82701 & 0.76690 & & & No & No \\
\hline \multirow[t]{2}{*}{$\mathrm{C}: \mathrm{N}$} & $\mathrm{NH}_{4}^{+}-\mathrm{N}$ & 0.00026 & 0.00160 & 22430.6 & 3561 & Yes & No \\
\hline & $\mathrm{NO}_{3}^{-}-\mathrm{N}$ & 0.00022 & 0.00122 & 23290.8 & 3636 & Yes & No \\
\hline \multirow[t]{2}{*}{ Application rate } & $\mathrm{NH}_{4}^{+}-\mathrm{N}$ & 0.00049 & 0.00254 & 28166.0 & 4401 & Yes & No \\
\hline & $\mathrm{NO}_{3}{ }^{-}-\mathrm{N}$ & 0.96310 & 0.88128 & & & No & No \\
\hline \multirow{2}{*}{$\begin{array}{l}\text { Residence time of } \\
\text { biochar in soil }\end{array}$} & $\mathrm{NH}_{4}^{+}-\mathrm{N}$ & 0.00028 & 0.00167 & 31334.8 & 4446 & Yes & No \\
\hline & $\mathrm{NO}_{3}^{-}-\mathrm{N}$ & 0.86308 & 0.80047 & & & No & No \\
\hline \multirow[t]{2}{*}{$\mathrm{N}$ fertilisation } & $\mathrm{NH}_{4}^{+}-\mathrm{N}$ & 0.00736 & 0.02027 & 19547.8 & 4206 & Yes & No \\
\hline & $\mathrm{NO}_{3}^{-}-\mathrm{N}$ & 0.53413 & 0.52056 & & & No & No \\
\hline \multirow[t]{2}{*}{ Soil texture } & $\mathrm{NH}_{4}^{+}-\mathrm{N}$ & 0.00003 & 0.00031 & 34582.5 & 4081 & Yes & No \\
\hline & $\mathrm{NO}_{3}^{-}-\mathrm{N}$ & 0.56463 & 0.66781 & & & No & No \\
\hline \multirow[t]{2}{*}{ Soil pH } & $\mathrm{NH}_{4}^{+}-\mathrm{N}$ & 0.01217 & 0.03210 & 38611.1 & 3481 & Yes & No \\
\hline & $\mathrm{NO}_{3}{ }^{-}-\mathrm{N}$ & 0.42414 & 0.46835 & & & No & No \\
\hline \multirow[t]{2}{*}{ Crop type } & $\mathrm{NH}_{4}^{+}-\mathrm{N}$ & 0.00021 & 0.00132 & 31228.5 & 4411 & Yes & No \\
\hline & $\mathrm{NO}_{3}{ }^{-}-\mathrm{N}$ & 0.58754 & 0.57800 & & & No & No \\
\hline \multirow{2}{*}{$\begin{array}{l}\text { Pot/field-based } \\
\text { study }\end{array}$} & $\mathrm{NH}_{4}^{+}-\mathrm{N}$ & 0.00024 & 0.00147 & 31266.5 & 4446 & Yes & No \\
\hline & $\mathrm{NO}_{3}{ }^{-}-\mathrm{N}$ & 0.86308 & 0.80047 & & & No & No \\
\hline \multirow{2}{*}{$\begin{array}{l}\text { Overall effect of } \\
\text { biochar application }\end{array}$} & $\mathrm{NH}_{4}^{+}-\mathrm{N}$ & 0.00024 & 0.00147 & 31266.5 & 4446 & Yes & No \\
\hline & $\mathrm{NO}_{3}^{-}-\mathrm{N}$ & 0.86308 & 0.80047 & & & No & No \\
\hline
\end{tabular}

Table 1: The result of publication bias used in this study. $\mathrm{n}$ represents the number of the cases. 


\begin{tabular}{lllll}
\hline & \multicolumn{2}{c}{$\mathbf{N H}_{\mathbf{4}}{ }^{+}-\mathbf{N}$} & \multicolumn{2}{c}{$\mathbf{N O}_{\mathbf{3}}{ }^{-}-\mathbf{N}$} \\
\hline & Moderator & \% Variation explained & Moderator & $\%$ Variation explained \\
\hline 1 & $\begin{array}{l}\text { Residence time of } \\
\text { biochar in soil }\end{array}$ & 28.1 & $\begin{array}{l}\text { Residence time of biochar } \\
\text { in soil }\end{array}$ & 21.7 \\
2 & Fertiliser & 14.4 & Biochar application rate & 16.6 \\
3 & Biochar application rate & 11.7 & Soil pH & 14.8 \\
4 & Soil pH & 11.6 & Pyrolysis temperature & 14.2 \\
5 & Pyrolysis temperature & 10 & Fertiliser & 11.1 \\
6 & Biochar BET & 5.6 & Biochar BET & 5.7 \\
7 & Biochar CEC & 4.4 & Feedstock & 5.3 \\
8 & Feedstock & 4.1 & Crop type & 3.7 \\
9 & Pyrolysis type & 3.1 & Biochar CEC & 2.7 \\
10 & Crop type & 3.1 & Pyrolysis type & 2.3 \\
11 & Biochar VOCs & 2 & Biochar VOCs & 1 \\
12 & Soil texture & 1.7 & Soil texture & 0.7 \\
13 & Experimental type & 0.2 & Experimental type & 0.2 \\
\hline
\end{tabular}

Table 2: Significance of explanatory variables by boosted regression tree (BRT) model in explaining the response of SIN under biochar effects. 


\begin{tabular}{|c|c|c|c|c|c|c|}
\hline & \multicolumn{3}{|c|}{$\mathbf{N H}_{4}{ }^{+}-\mathbf{N}$} & \multicolumn{3}{|c|}{$\mathrm{NO}_{3}{ }^{-}-\mathrm{N}$} \\
\hline & Factor 1 & Factor 2 & $\begin{array}{l}\text { Interaction } \\
\text { size }\end{array}$ & Factor 1 & Factor 2 & $\begin{array}{l}\text { Interaction } \\
\text { size }\end{array}$ \\
\hline 1 & Fertiliser & $\begin{array}{l}\text { Biochar application } \\
\text { rate }\end{array}$ & 5.63 & $\begin{array}{l}\text { Biochar application } \\
\text { rate }\end{array}$ & $\begin{array}{l}\text { Pyrolysis tempera } \\
\text { ture }\end{array}$ & 35.17 \\
\hline 2 & Soil pH & Biochar CEC & 5.12 & Soil pH & $\begin{array}{l}\text { Biochar applicati } \\
\text { on rate }\end{array}$ & 13.93 \\
\hline 3 & Soil pH & $\begin{array}{l}\text { Biochar application } \\
\text { rate }\end{array}$ & 4.19 & $\begin{array}{l}\text { Biochar application } \\
\text { rate }\end{array}$ & $\begin{array}{l}\text { Biochar BET surf } \\
\text { ace area }\end{array}$ & 10.74 \\
\hline 4 & Fertiliser & $\begin{array}{l}\text { Residence time of b } \\
\text { iochar in soil }\end{array}$ & 3.47 & $\begin{array}{l}\text { Biochar application } \\
\text { rate }\end{array}$ & Feedstock & 8.84 \\
\hline 5 & Fertiliser & Biochar CEC & 2.46 & Fertiliser & $\begin{array}{l}\text { Biochar applicatio } \\
n \text { rate }\end{array}$ & 8.55 \\
\hline 6 & Fertiliser & Soil pH & 2.13 & Soil pH & $\begin{array}{l}\text { Pyrolysis tempera } \\
\text { ture }\end{array}$ & 3.14 \\
\hline 7 & Fertiliser & Feedstock & 2.05 & $\begin{array}{l}\text { Residence time of bi } \\
\text { ochar in soil }\end{array}$ & $\begin{array}{l}\text { Pyrolysis tempera } \\
\text { ture }\end{array}$ & 1.80 \\
\hline 8 & Crop Type & Soil pH & 1.67 & $\begin{array}{l}\text { Residence time of } \\
\text { biochar in soil }\end{array}$ & $\begin{array}{l}\text { Biochar applicati } \\
\text { on rate }\end{array}$ & 1.56 \\
\hline
\end{tabular}

Table 3: The 8 most important pairwise interactions by boosted regression tree (BRT) model to address the factor interactions. 


\begin{tabular}{|c|c|}
\hline Gap & Description \\
\hline Production condition & $\begin{array}{l}\text { Data should be fully reported including pyrolysis time interval } \\
\text { of biochar production, activation type, atmospheric pressure, } \\
\text { feedstock properties e.g. origin, elemental analysis }\end{array}$ \\
\hline Biochar properties & $\begin{array}{l}\text { Data should be fully reported including surface area, CEC, } \\
\text { VOCs, particle size, EC, adsorption capacity, and the size of } \\
\text { biochar particles }\end{array}$ \\
\hline Biochar application rate & Very limited studies on high rate $(>10 \%)$ \\
\hline Residence time of biochar in soil & Very limited studies on long term ( $>5$ years) \\
\hline $\mathrm{N}$ fertiliser type & $\begin{array}{l}\mathrm{C}: \mathrm{N} \text { ratio of organic fertiliser combined with biochar should } \\
\text { be reported }\end{array}$ \\
\hline $\begin{array}{l}\text { Environmental conditions and soil } \\
\text { management }\end{array}$ & $\begin{array}{l}\text { Data should be fully reported including meteorological data, } \\
\text { tillage, cultivation, soil organic matter, crop type }\end{array}$ \\
\hline $\begin{array}{l}\text { Effects of factor combination } \\
\text { which influences biochar effects on } \\
\text { SIN }\end{array}$ & $\begin{array}{l}\text { Long-term experiments that quantify the effects of factor } \\
\text { combination (e.g. fertiliser type and biochar application rate, } \\
\text { soil pH and biochar application rate, feedstock type and } \\
\text { biochar application rate, etc.) on SIN. }\end{array}$ \\
\hline
\end{tabular}

Table 4: Research gaps in the current knowledge on the effects of biochar on soil inorganic $\mathrm{N}$ 
Figure S1: PRISMA statement (Moher et al., 2009)
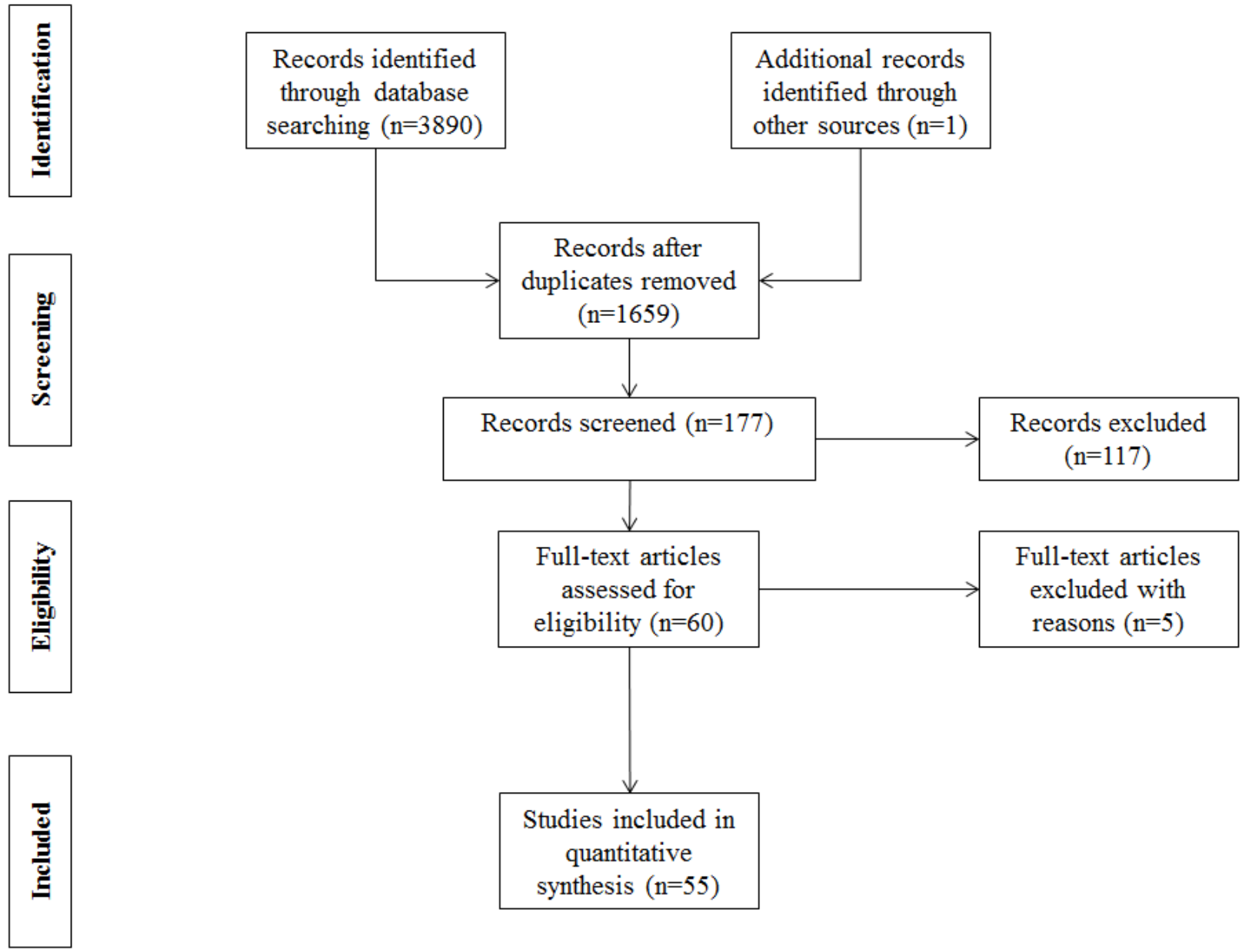
Figure S2: Weight-rank plot

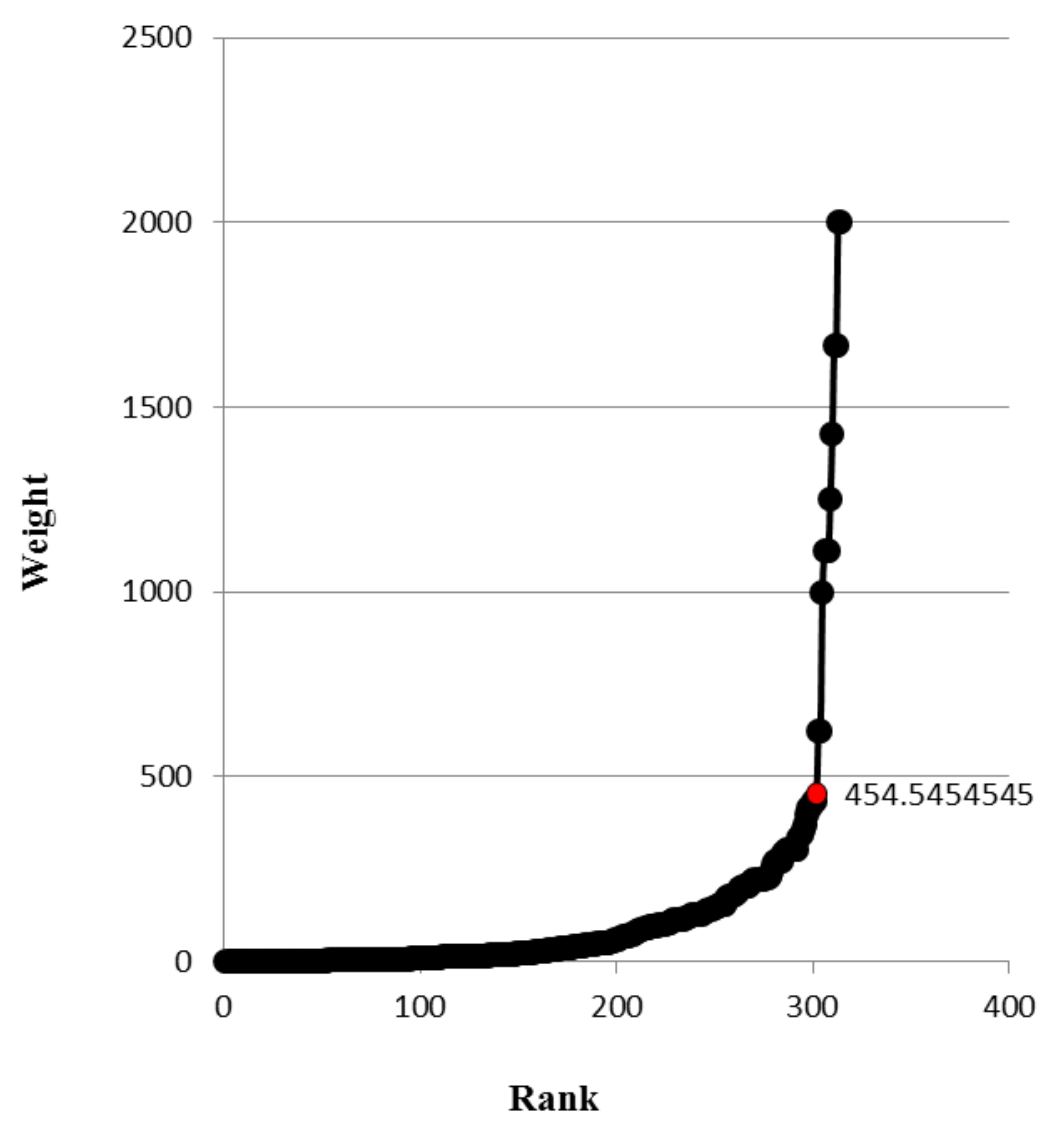

The weight range was generated from $\mathrm{RR}\left(\mathrm{NH}_{4}{ }^{+}-\mathrm{N}\right)$ under the effects of biochar BET surface area. The red dot was set as the threshold for the weight.

In forest plots, a weight threshold 1111 was set to all plots of both $\mathrm{N}$ forms. On average about 3.4\% (for $\mathrm{NH}_{4}{ }^{+}-\mathrm{N}$ ) and $8.8 \%$ (for $\mathrm{NO}_{3}{ }^{-}-\mathrm{N}$ ) of cases were converted to the threshold in forest plots. 
Figure S3: Influence of experiment design on $\mathrm{NH}_{4}{ }^{+}-\mathrm{N}$ and $\mathrm{NO}_{3}{ }^{-} \mathrm{N}$ availability in soil. Symbols represent mean effect sizes (percentage of change in $\mathrm{NH}_{4}{ }^{+}-\mathrm{N}$ (a) and $\mathrm{NO}_{3}{ }^{-}-\mathrm{N}$ content (b)) with $95 \%$ confidence intervals. The numbers shown on the right correspond to observations in each class upon which the statistical analysis is based. The dotted line indicates the mean effect size for all $\mathrm{pH}$ ranges when biochar is co-applied to soil.

a

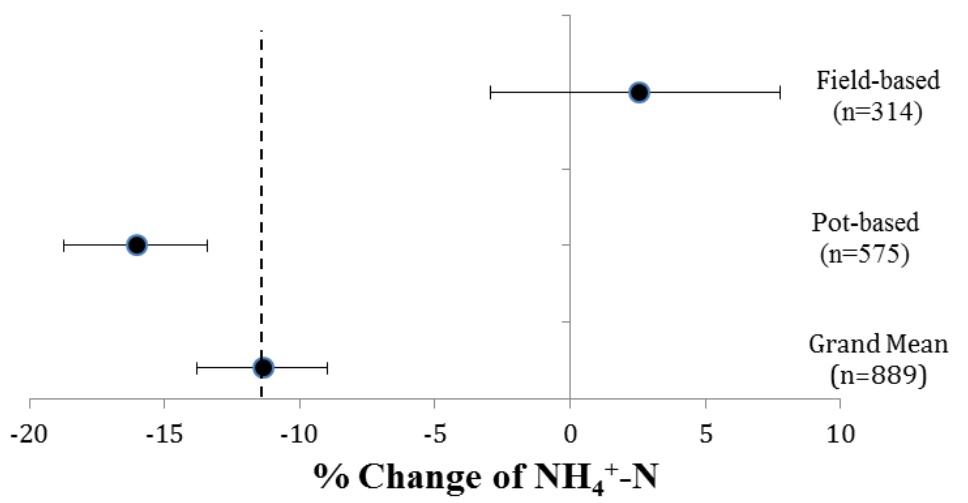

Qbetween $=41.4739, \mathrm{df}=1, \mathrm{P}(\mathrm{rand})=0.001$

b

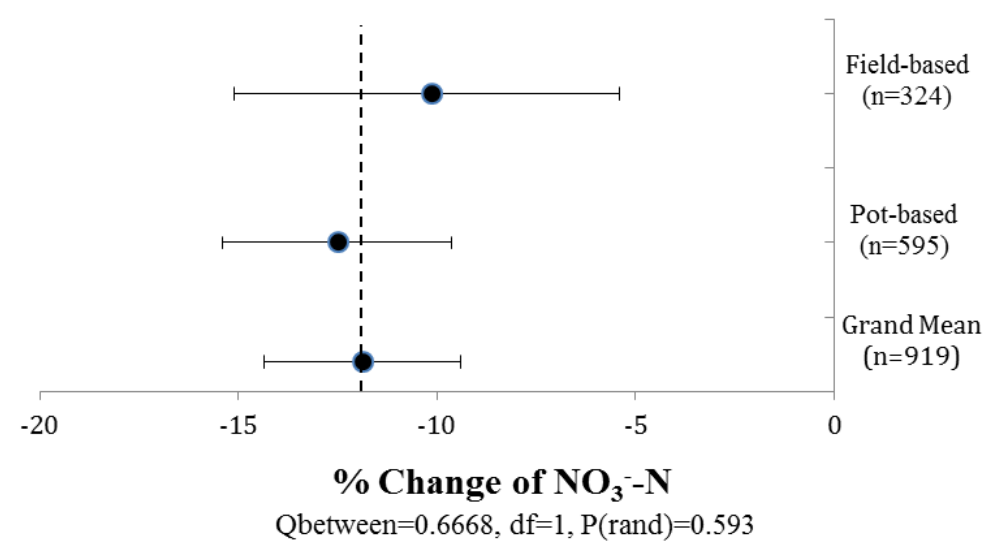


Figure S4: Partial dependence plots (A, B, C, D, E) and fitted values (F, G, H, I, K) showing the effects of biochar on soil $\mathrm{NH}_{4}{ }^{+}-\mathrm{N}$. The fitted function shows the relationship between effect sizes and an explanatory variable while all other explanatory variables are kept constant at their mean level.
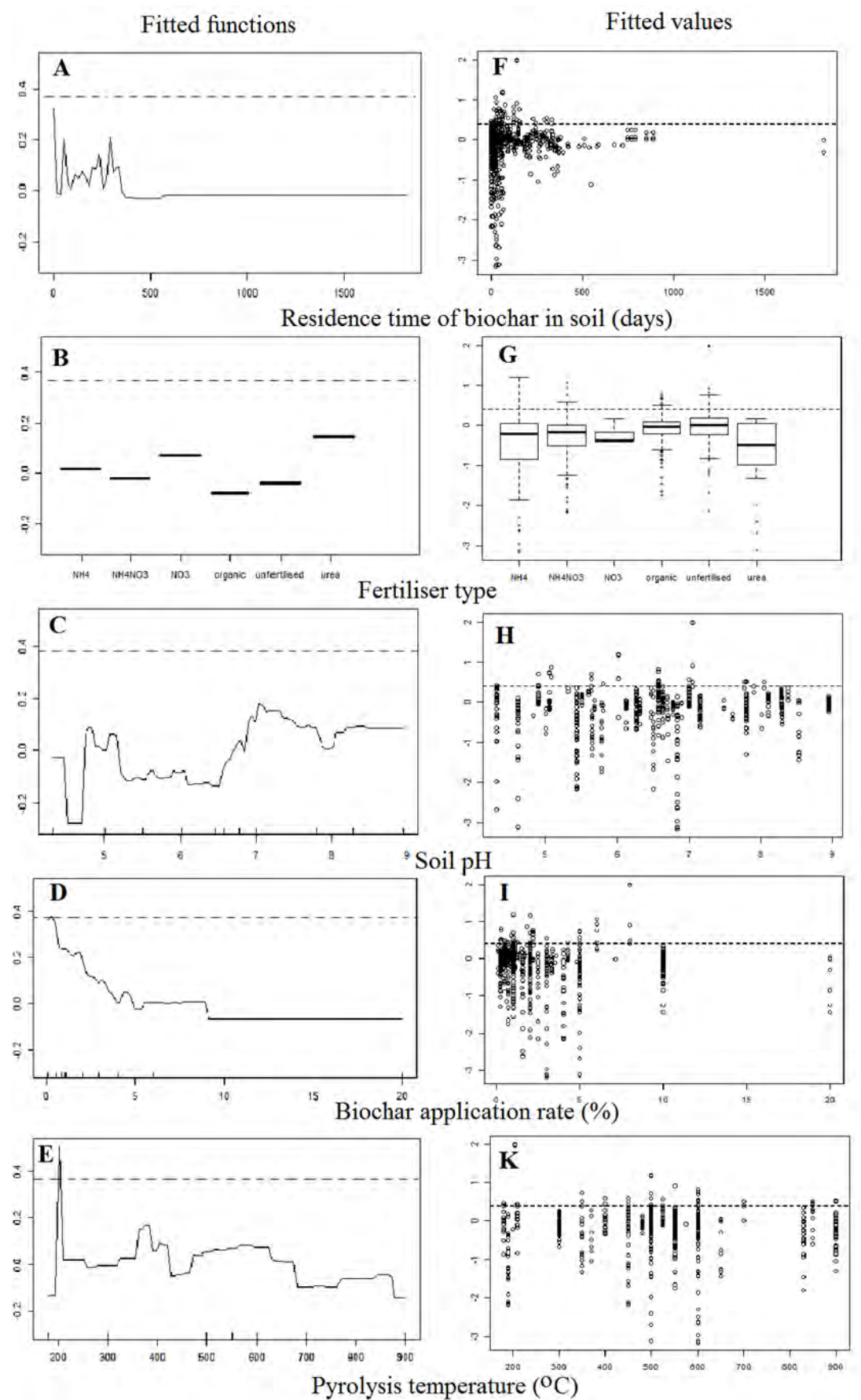
Figure S5: Partial dependence plots (A, B, C, D, E) and fitted values (F, G, H, I, K) showing the effects of biochar on soil $\mathrm{NO}_{3}^{-}-\mathrm{N}$. The fitted function shows the relationship between $\mathrm{ES}$ and an explanatory variable while all other explanatory variables are kept constant at their mean level.
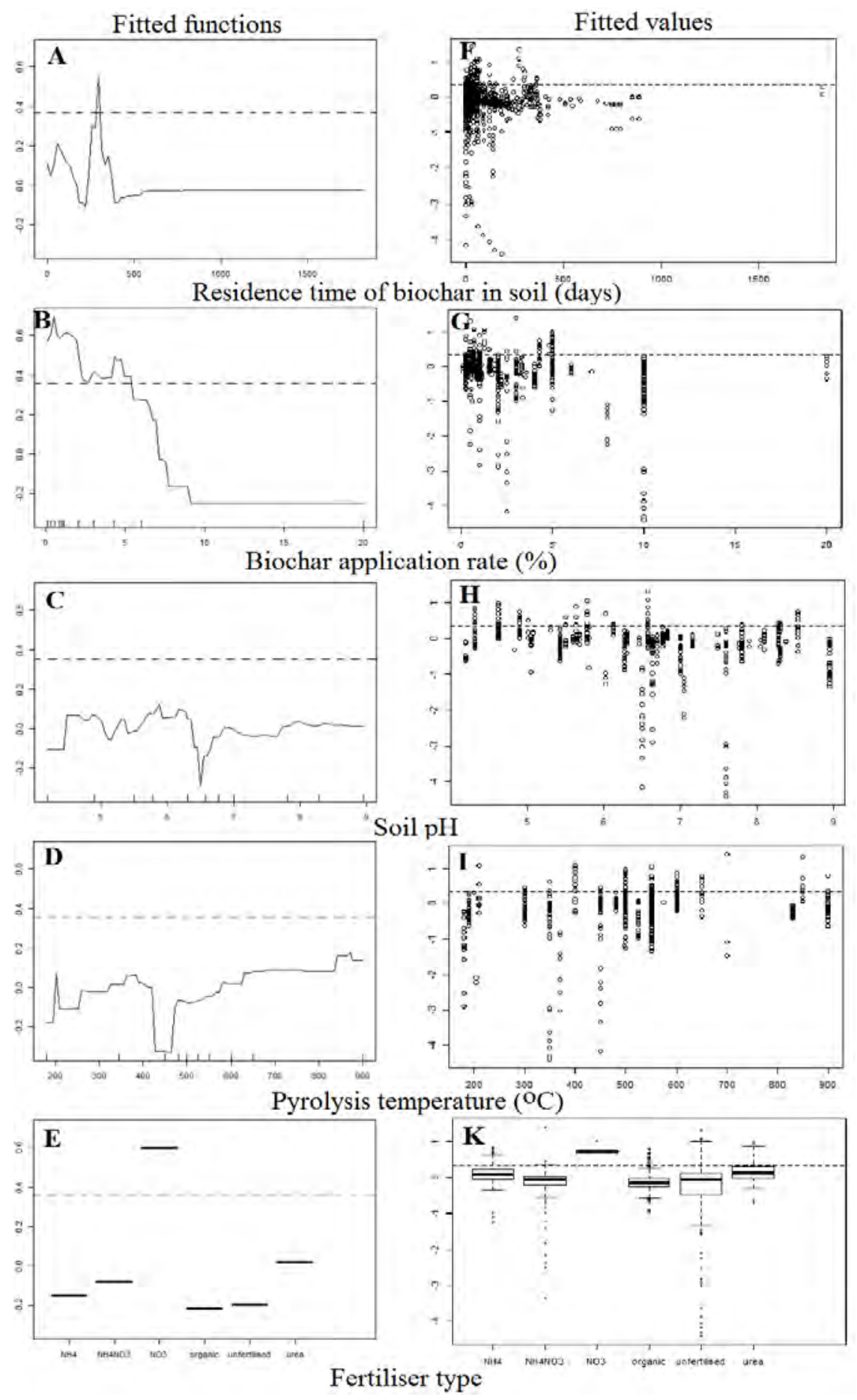


\begin{tabular}{|c|c|c|c|c|c|c|c|c|c|c|c|c|c|}
\hline & $\begin{array}{l}\text { Feedsto } \\
\text { ck }\end{array}$ & $\begin{array}{l}\text { Pyrolysis } \\
\text { temperatu } \\
\text { re }\end{array}$ & $\begin{array}{l}\text { Pyrolys } \\
\text { is type }\end{array}$ & $\begin{array}{l}\text { BET surf } \\
\text { ace }\end{array}$ & $\begin{array}{l}\text { Bioch } \\
\text { ar CE } \\
\text { C }\end{array}$ & $\begin{array}{l}\text { Biocha } \\
\text { r VOC } \\
\text { s }\end{array}$ & $\begin{array}{l}\text { Biochar ra } \\
\text { te }\end{array}$ & $\begin{array}{l}\text { Residence ti } \\
\text { me in soil }\end{array}$ & $\begin{array}{l}\text { Soil textu } \\
\text { re }\end{array}$ & $\begin{array}{l}\text { Soil p } \\
\mathrm{H}\end{array}$ & $\begin{array}{l}\text { Fertilis } \\
\text { er }\end{array}$ & $\begin{array}{l}\text { Experime } \\
\text { nt type }\end{array}$ & $\begin{array}{l}\text { Crop } \\
\text { type }\end{array}$ \\
\hline Feedstock & 0.00 & 0.86 & 0.32 & 0.03 & 0.00 & 0.05 & 0.32 & 0.46 & 0.00 & 0.11 & 2.05 & 0.00 & 0.04 \\
\hline $\begin{array}{l}\text { Pyrolysis temper } \\
\text { ature }\end{array}$ & 0.00 & 0.00 & 0.03 & 0.03 & 0.06 & 0.08 & 0.44 & 0.76 & 0.02 & 0.71 & 0.50 & 0.03 & 1.20 \\
\hline Pyrolysis type & 0.00 & 0.00 & 0.00 & 0.02 & 0.00 & 0.00 & 0.57 & 0.43 & 0.01 & 0.04 & 0.07 & 0.00 & 0.04 \\
\hline BET surface & 0.00 & 0.00 & 0.00 & 0.00 & 0.04 & 0.00 & 0.05 & 0.11 & 0.00 & 0.03 & 0.87 & 0.00 & 0.00 \\
\hline Biochar CEC & 0.00 & 0.00 & 0.00 & 0.00 & 0.00 & 0.00 & 0.70 & 1.15 & 0.00 & 5.12 & 2.46 & 0.00 & 0.01 \\
\hline Biochar VOCs & 0.00 & 0.00 & 0.00 & 0.00 & 0.00 & 0.00 & 0.02 & 0.23 & 0.00 & 0.13 & 0.20 & 0.00 & 0.00 \\
\hline Biochar rate & 0.00 & 0.00 & 0.00 & 0.00 & 0.00 & 0.00 & 0.00 & 0.59 & 0.09 & 4.19 & 5.63 & 0.00 & 0.32 \\
\hline $\begin{array}{l}\text { Residence time i } \\
\text { n soil }\end{array}$ & 0.00 & 0.00 & 0.00 & 0.00 & 0.00 & 0.00 & 0.00 & 0.00 & 0.04 & 0.47 & 3.47 & 0.06 & 0.16 \\
\hline Soil texture & 0.00 & 0.00 & 0.00 & 0.00 & 0.00 & 0.00 & 0.00 & 0.00 & 0.00 & 0.03 & 0.32 & 0.00 & 0.00 \\
\hline Soil pH & 0.00 & 0.00 & 0.00 & 0.00 & 0.00 & 0.00 & 0.00 & 0.00 & 0.00 & 0.00 & 2.13 & 0.01 & 1.67 \\
\hline Fertiliser & 0.00 & 0.00 & 0.00 & 0.00 & 0.00 & 0.00 & 0.00 & 0.00 & 0.00 & 0.00 & 0.00 & 0.01 & 1.06 \\
\hline Experiment type & 0.00 & 0.00 & 0.00 & 0.00 & 0.00 & 0.00 & 0.00 & 0.00 & 0.00 & 0.00 & 0.00 & 0.00 & 0.03 \\
\hline Crop type & 0.00 & 0.00 & 0.00 & 0.00 & 0.00 & 0.00 & 0.00 & 0.00 & 0.00 & 0.00 & 0.00 & 0.00 & 0.00 \\
\hline
\end{tabular}

Table S1: Pairwise interactions by boosted regression tree (BRT) model to address the factor interactions considering the effects of biochar on soil $\mathrm{NH}_{4}{ }^{+}-\mathrm{N}$. Values were interaction sizes. 


\begin{tabular}{|c|c|c|c|c|c|c|c|c|c|c|c|c|c|}
\hline & $\begin{array}{l}\text { Feedsto } \\
\text { ck }\end{array}$ & $\begin{array}{l}\text { Pyrolysis } \\
\text { temperat } \\
\text { ure }\end{array}$ & $\begin{array}{l}\text { Pyrolysis t } \\
\text { ype }\end{array}$ & $\begin{array}{l}\text { BET surf } \\
\text { ace }\end{array}$ & $\begin{array}{l}\text { Bioch } \\
\text { ar CE } \\
\text { C }\end{array}$ & $\begin{array}{l}\text { Biocha } \\
\text { r VOC } \\
\text { s }\end{array}$ & $\begin{array}{l}\text { Biochar } r \\
\text { ate }\end{array}$ & $\begin{array}{l}\text { Residence } \\
\text { time in so } \\
\text { il }\end{array}$ & $\begin{array}{l}\text { Soil te } \\
\text { xture }\end{array}$ & $\begin{array}{l}\text { Soil p } \\
\mathrm{H}\end{array}$ & $\begin{array}{l}\text { Fertilis } \\
\text { er }\end{array}$ & $\begin{array}{l}\text { Experi } \\
\text { ment ty } \\
\text { pe }\end{array}$ & Crop type \\
\hline Feedstock & 0.00 & 0.14 & 0.70 & 0.11 & 0.00 & 0.02 & 8.84 & 0.38 & 0.00 & 0.25 & 1.05 & 0.00 & 0.05 \\
\hline $\begin{array}{l}\text { Pyrolysis temp } \\
\text { erature }\end{array}$ & 0.00 & 0.00 & 0.05 & 0.18 & 0.01 & 0.16 & 35.17 & 1.80 & 0.01 & 3.14 & 1.22 & 0.00 & 1.38 \\
\hline Pyrolysis type & 0.00 & 0.00 & 0.00 & 0.01 & 0.00 & 0.01 & 0.50 & 0.09 & 0.25 & 0.09 & 0.08 & 0.00 & 0.16 \\
\hline BET surface & 0.00 & 0.00 & 0.00 & 0.00 & 0.00 & 0.00 & 10.74 & 0.10 & 0.00 & 0.39 & 1.10 & 0.00 & 0.00 \\
\hline Biochar CEC & 0.00 & 0.00 & 0.00 & 0.00 & 0.00 & 0.00 & 0.02 & 0.05 & 0.00 & 0.12 & 0.11 & 0.00 & 0.00 \\
\hline Biochar VOCs & 0.00 & 0.00 & 0.00 & 0.00 & 0.00 & 0.00 & 0.03 & 0.08 & 0.00 & 0.05 & 0.21 & 0.00 & 0.02 \\
\hline Biochar rate & 0.00 & 0.00 & 0.00 & 0.00 & 0.00 & 0.00 & 0.00 & 1.56 & 0.01 & 13.93 & 8.55 & 0.00 & 0.21 \\
\hline $\begin{array}{l}\text { Residence time } \\
\text { in soil }\end{array}$ & 0.00 & 0.00 & 0.00 & 0.00 & 0.00 & 0.00 & 0.00 & 0.00 & 0.02 & 0.62 & 0.81 & 0.00 & 0.66 \\
\hline Soil texture & 0.00 & 0.00 & 0.00 & 0.00 & 0.00 & 0.00 & 0.00 & 0.00 & 0.00 & 0.06 & 0.01 & 0.00 & 0.00 \\
\hline Soil pH & 0.00 & 0.00 & 0.00 & 0.00 & 0.00 & 0.00 & 0.00 & 0.00 & 0.00 & 0.00 & 1.45 & 0.00 & 0.38 \\
\hline Fertiliser & 0.00 & 0.00 & 0.00 & 0.00 & 0.00 & 0.00 & 0.00 & 0.00 & 0.00 & 0.00 & 0.00 & 0.00 & 0.53 \\
\hline $\begin{array}{l}\text { Experiment ty } \\
\text { pe }\end{array}$ & 0.00 & 0.00 & 0.00 & 0.00 & 0.00 & 0.00 & 0.00 & 0.00 & 0.00 & 0.00 & 0.00 & 0.00 & 0.08 \\
\hline Crop type & 0.00 & 0.00 & 0.00 & 0.00 & 0.00 & 0.00 & 0.00 & 0.00 & 0.00 & 0.00 & 0.00 & 0.00 & 0.00 \\
\hline
\end{tabular}

Table S2: Pairwise interactions by boosted regression tree (BRT) model to address the factor interactions considering the effects of biochar on soil $\mathrm{NO}_{3}{ }^{-}-\mathrm{N}$. Values were interaction sizes. 